\title{
PRIMARY PHASES AND NATURAL WEATHERING OF OLD LEAD-ZINC PYROMETALLURGICAL SLAG FROM PŘíBRAM, CZECH REPUBLIC
}

\author{
VOJTĚCH ETTLER ${ }^{\S}$ \\ Institute of Geochemistry, Mineralogy and Mineral Resources, Charles University, Albertov 6, 12843 Prague 2, \\ Czech Republic
}

OLIVIER LEGENDRE AND FRANÇOISE BODÉNAN

BRGM, 3, avenue Claude Guillemin, F-45 060 Orléans, France

JEAN-CLAUDE TOURAY

Institut des Sciences de la Terre, Université d'Orléans, Rue Léonard de Vinci, F-45 072 Orléans, France

\begin{abstract}
Pyrometallurgical slag, produced 100-150 years ago from lead-zinc ores in the smelting region of Př́bram, Czech Republic, contains elevated amounts of $\mathrm{Zn}$ and $\mathrm{Pb}$. Knowledge of the distribution of these elements in the main phases and an investigation of natural weathering features represent the first step in the environmental assessment related to dumping of metallurgical slag. Optical microscopy, scanning electron microscopy (SEM/EDS), X-ray diffraction (XRD) and electron-beam microanalysis (EMPA) were used to identify the silicate, oxide, sulfide and metallic phases. The study focused on silicates and oxides, and the major constituents of the slag proved to be clinopyroxene, melilite, olivine, spinel and glass. A substantial amount of zinc, initially dissolved in the silicate melt, is held by zinc-rich end-members of the spinel (gahnite, up to $19.9 \mathrm{wt} \% \mathrm{ZnO}$ ) and silicates (e.g., hardystonite, up to $10.5 \mathrm{wt} \% \mathrm{ZnO}$ ). Lead, in contrast, behaves as an "incompatible element" and is likely to be concentrated in the residual matrix glass. Two distinct glasses were identified: (i) transparent (surface) glass from the quenched borders of slag fragments, and (ii) opaque (matrix) glass, which forms a black matrix in the center of the fragments. These glasses contain important amounts of lead and zinc, up to $3.72 \mathrm{wt} \% \mathrm{PbO}$ and $9.80 \mathrm{wt} \% \mathrm{ZnO}$, partly in the form of droplets (generally <1 $\mu \mathrm{m}$ ) composed of galena, metallic lead, $\mathrm{ZnS}$ and other sulfide and metallic phases and alloys. Two features attributed to natural weathering, found mainly on the surface of chilled-glass borders, were identified in the slag: (i) deposition of a Fe-and Pb-rich veneer, and (ii) selective leaching of superficial glass revealing, with respect to unaltered glass, the mobilization of $\mathrm{Ca}, \mathrm{Fe}, \mathrm{Na}$, $\mathrm{K}$, and $\mathrm{Zn}$.
\end{abstract}

Keywords: metallurgical slag, mineralogy, weathering, heavy metals, lead, zinc, Př́ibram, Czech Republic.

SOMMAIRE

Les scories métallurgiques, déchets de la métallurgie du plomb, provenant du site de Př́íbram en République tchèque, offrent l'opportunité d'étudier des milieux riches en $\mathrm{Pb}$ et $\mathrm{Zn}$ et de localiser ces éléments dans les phases majeures (silicates, oxydes, sulfures et phases métalliques). Cette étude représente une approche préliminaire à l'évaluation du risque environnemental lié au stockage de ce type de déchet. La microscopie optique et électronique (MEB/EDS), la diffraction des rayons X (DRX), ainsi que la microanalyse électronique (ME) ont été mises en oeuvre. L'étude, focalisée sur les silicates et les oxydes, a révélé la présence de clinopyroxène, de mélilite, de phases de type olivine, de spinelle et d'une phase vitreuse. Le Zn paraît piégé dans des solutions solides, qu'il s'agisse de spinelle (jusqu'à $19.9 \% \mathrm{ZnO}$ en poids) ou des silicates (jusqu'à $10.5 \% \mathrm{ZnO}$ dans la mélilite). $\mathrm{Pb}$, élement à comportement "incompatible", est plutôt concentré dans le verre résiduel. Dans les scories étudiées, le verre est de deux types: (i) un verre transparent formant une mince couche à la bordure figée des blocs moulés de scorie, et (ii) un verre opaque formant une matrice au cœur des blocs. Ces verres renferment jusqu'à $3.7 \% \mathrm{PbO}$, et $9.8 \% \mathrm{ZnO}$, en partie sous forme de gouttelettes métallifères d'un diamètre parfois inférieur à $1 \mu \mathrm{m}$. Elles sont composées soit de galène, de plomb natif, de ZnS, d'autres sulfures ou de phases métalliques éventuellement sous forme d'alliages complexes. Deux manifestations d'altération naturelle ont été identifiées sur et dans le verre de bordure figée des scories étudiées. Il s'agit (i) de précipitation des phases secondaires riches en $\mathrm{Fe}$ et $\mathrm{Pb}$, et (ii) d'un lessivage sélectif du verre montrant la mobilisation de $\mathrm{Ca}, \mathrm{Fe}, \mathrm{Na}, \mathrm{K}$ et $\mathrm{Zn}$.

Mots-clés: scorie métallurgique, minéralogie, altération, métaux lourds, plomb, zinc, Př́íbram, République tchèque.

§E-mail address: ettler@mail.natur.cuni.cz 


\section{INTRODUCTION}

Slags and similar vitrified waste-products are generally either dumped at waste-disposal sites or used for civil engineering purposes, such as road construction or concrete manufacture (Atzeni et al. 1996, Mandin 1999, Gervais et al. 1999). However, they commonly contain high concentrations of heavy metals like $\mathrm{Pb}$ and $\mathrm{Zn}$. Because of environmental concerns, an understanding of the long-term behavior of these materials is essential. A number of studies focused on metallurgical slags have been published recently (Chaudhuri \& Newesely 1993, Kucha et al. 1996, Gee et al. 1997, Lastra et al. 1998), but they provide only limited information on the accurate chemical composition of major phases found in the slags.

This paper concerns old lead-zinc metallurgical slag from the Prríbram district, in the Czech Republic, and is especially devoted to i) a description and quantitative analysis of major constituents of the slag (silicates, oxides and glass), with special emphasis on the localization of $\mathrm{Zn}$ and $\mathrm{Pb}$ in their structure, and ii) an investigation of the effects of weathering on these phases. Such a study represents the first step in the environmental assessment related to dumping of metallurgical slags and provides the basis for a thorough environmental study. The results concerning zinc partitioning between crystalline and glassy phases in slag are given elsewhere (Ettler et al. 2000).

\section{BACKGROUND INFORMATION}

Historical metallurgical slags are assumed to be rich in heavy metals because they were produced, together with large amounts of sulfide matte, using less sophisticated smelting processes than are the rule today. Studies of such slags are of special interest because they present an opportunity to evaluate the incorporation of $\mathrm{Zn}$ and $\mathrm{Pb}$ at relatively high levels into silicate, oxide and glass phases. They also provide an invaluable opportunity to assess the stability of these phases when exposed to weathering over a century or more.

The slag material studied for this project is from the district of Př́bram, $60 \mathrm{~km}$ southwest of Prague (Fig. 1). The Př́bram area has a long history of lead-silver mining and smelting, probably dating from the Celtic civilization $\left(\mathrm{VI}^{\mathrm{th}}-\mathrm{I}^{\mathrm{st}}\right.$ century B.C.). The relics of a simple furnace facility have been found amongst archeological excavations dating from the XIII ${ }^{\text {th }}$ century and located about 7 km southwest of Př́ibram (Kudrnáč 1987, Hampejs 1971). Subsequently, the processing of Ag$\mathrm{Pb}$ ores mined in the area formed an important industrial activity from 1786 until the 1970s. Smelting at a location about $4 \mathrm{~km}$ northwest of the center of Př́ibram (Fig. 1) produced, over a period of two centuries, a large amount of waste material $(1.8 \mathrm{Mt})$ dumped in the vicinity of the smelter. The stockpiles and waste heaps contain mainly silicate slag and represent a potential source of water pollution. Soil pollution in the area, attributed mainly to emissions from the smelter, was studied by Borůvka et al. (1996) and by Rieuwerts \& Farago (1996). Except for preliminary studies by Legendre et al. (1998) and Ettler et al. (1999), the environmental influence of material dumped on this site has not been assessed.

The slag is an end-product of lead and silver production in the area. As described in the literature, the $\mathrm{Pb}-\mathrm{Ag}$ ores contained about $70 \% \mathrm{~Pb}$ and were roasted in a Dwight-Lloyd sintering plant (Gilchrist 1989). The roasted ore (sinter), scrap-iron additive (flux), limy additive $\left(\mathrm{CaCO}_{3}\right)$, silica source (gangue or recharge slag), and coke were mixed and served as a charge for smelting in a blast furnace (Gilchrist 1989, Gill 1980, K. Vurm, pers. commun., 1999). A well-balanced mixture of these components helped to maintain furnace temperatures around a mean value of $1300^{\circ} \mathrm{C}$ (rising occasionally up to $1440^{\circ} \mathrm{C}$ ) (K. Vurm, pers. commun., 1999). The density and viscosity of the molten slag had to be kept low enough to ensure the gravity separation of metal-rich liquids (sulfide matte, quasi-pure molten metals) containing elevated amounts of the desired metals ( $\mathrm{Pb}, \mathrm{Ag}$, and others). Silicate slag floated on the surface of the sulfide matte and concentrated the oxide components of the silicate gangue and additives. Slag also contained metal-rich droplets unable to decant in time during the smelting process (Gilchrist 1989). In contrast with the other metals, most of the $\mathrm{Zn}$ was vaporized or dissolved in the liquid silicate slag (up to $20 \%$ $\mathrm{ZnO}$, Gilchrist 1989). The vaporized $\mathrm{Zn}$ could subsequently condense, forming oxides or $\mathrm{ZnS}$ globules trapped by molten slag (Chaudhuri \& Newesely 1993).

\section{Materials And Methods}

The slag was sampled from dumps near the old smelter located at Lhota, $4 \mathrm{~km}$ northwest of Příbram (Fig. 1). About 70 samples were collected from the oldest stockpile, where the age of the slag is estimated at around 100-150 years. The slag was formed as massive casts molded in cone-shaped ladles weighing up to $120 \mathrm{~kg}$. Sulfide matte, which in some cases occurs at the bottom of the casts, was sampled, as well as the main silicate-rich slag material.

The slag is composed of macroscopically homogeneous, massive, vitreous material of gray, black or greenish color. It is typically coarse-grained in the central part of the casts and quenched at the surface where there is usually a layer of glass a few millimeters thick. Fragments of slag several centimeters in size were collected and classified according to their macroscopic characters, their abundance and their position on the dumps.

Representative samples were studied in thin and polished sections using a polarizing microscope with transmitted and reflected light. Subsequently, each sample was examined using a JEOL JSM 6400 scan- 


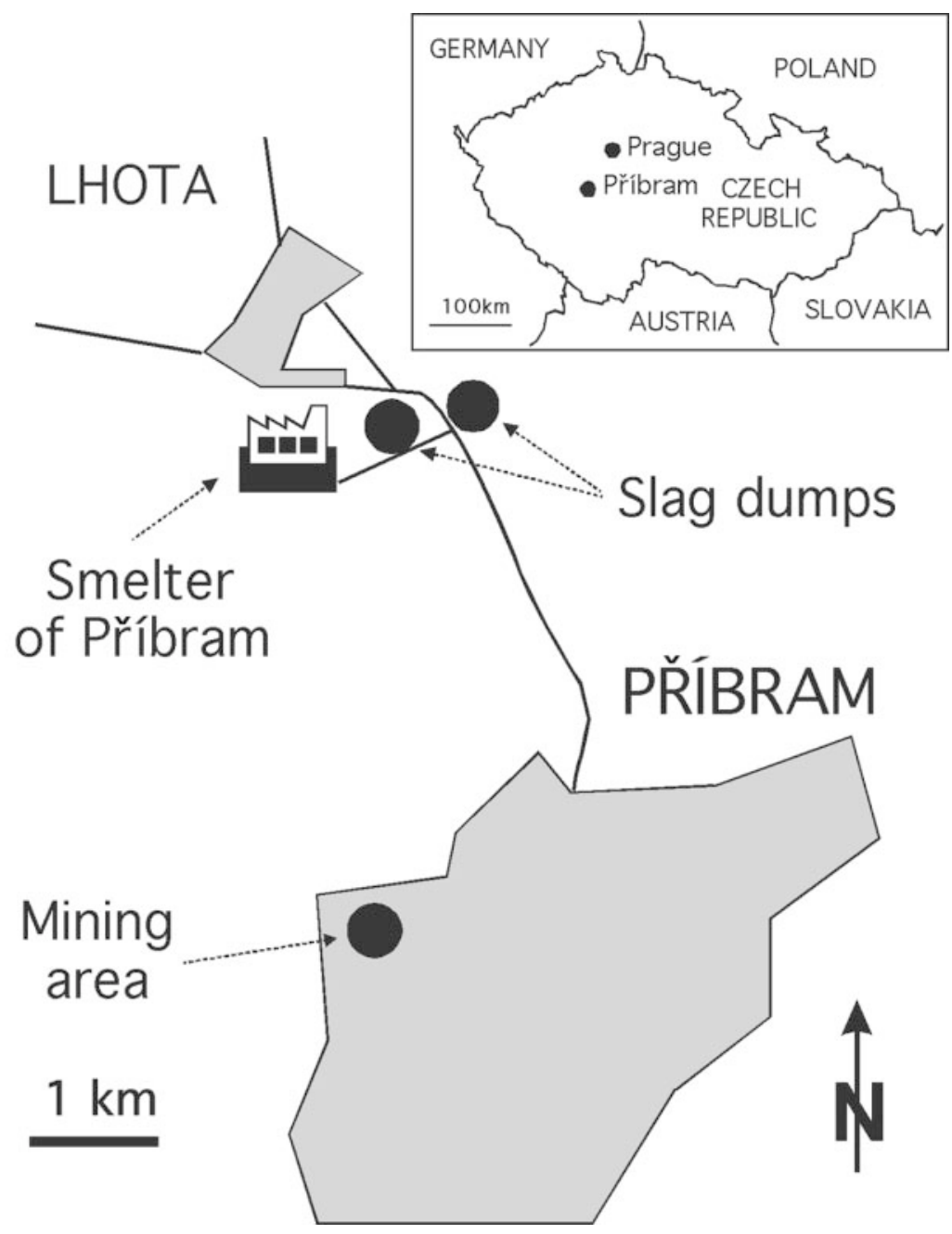

FIG. 1. Geographical location of the mining and smelting district of Př́bram, Czech Republic.

ning electron microscope (SEM) equipped with a KEVEX Delta energy-dispersion spectrometer (EDS) at the École Supérieure de l'Énergie et des Matériaux (Université d'Orléans). A CAMECA SX-50 electron microprobe analyzer (EMPA) at BRGM-CNRS Orléans was used to perform all quantitative analyses. For silicate and oxide phases, analytical conditions were: accelerating voltage $15 \mathrm{kV}$, beam current $12 \mathrm{nA}$ and counting time $10 \mathrm{~s}$ (except $\mathrm{Pb}$, As and $\mathrm{S}$, where counting time increased to $20 \mathrm{~s}$ ). The following standards were used for silicate and oxide phases: albite ( $\mathrm{Si}, \mathrm{Na})$, $\mathrm{K}$-feldspar $(\mathrm{K})$, forsterite $(\mathrm{Mg})$, hematite $(\mathrm{Fe})$, andradite $(\mathrm{Ca})$, zincite $(\mathrm{Zn})$, galena $(\mathrm{Pb})$, synthetic $\mathrm{Cr}_{2} \mathrm{O}_{3}(\mathrm{Cr})$, pyrite (S), synthetic $\mathrm{MnTiO}_{3}$ (Ti, Mn), synthetic AsGa
(As), and $\mathrm{Al}_{2} \mathrm{O}_{3}(\mathrm{Al})$. For metals and sulfides, analytical conditions were: accelerating voltage $20 \mathrm{kV}$, beam current $20 \mathrm{nA}$ and counting time $10 \mathrm{~s}$ for all the elements. The following standards were used for metals and sulfides: sphalerite $(\mathrm{Zn})$, pyrite $(\mathrm{Fe}, \mathrm{S})$, stibnite $(\mathrm{Sb})$, cassiterite ( $\mathrm{Sn})$, synthetic AsGa (As), pure copper $(\mathrm{Cu})$, and galena $(\mathrm{Pb})$. The phase assemblages of selected samples were determined using a Siemens D-500 Xray powder diffractometer (XRD) with $\mathrm{Cu} K \alpha$ radiation operating at $25 \mathrm{~mA}$ and $35 \mathrm{kV}$, from $5^{\circ}$ to $80^{\circ}$, by steps of $0.01^{\circ}$ and with a counting time of $10 \mathrm{~s}$ (École Supérieure de l'Énergie et des Matériaux, Université d'Orléans). 


\section{Petrography of the Slag}

The slag is composed essentially of high-temperature $\mathrm{Ca}-\mathrm{Fe}$ silicates and aluminosilicates (olivine group, melilite and clinopyroxene), oxides (spinels), sulfides, arsenides, metallic phases and glass (Table 1). The textural features of the slag depend upon the cooling rates within the casts, which in turn depend on distance from the cast surface. The glassy outer parts of the casts contain sporadic microcrystallites of melilite and a finegrained olivine-group mineral. Crystals in this surface zone show textures of rapid growth, with characteristic dendritic shapes. The holocrystalline inner parts of the casts consist of prismatic well-formed crystals (Fig. 2b).

Deeper zones in the casts (more than $0.5 \mathrm{~mm}$ from the outside) are typically coarse-grained, with significantly larger crystals located $20 \mathrm{~cm}$ from the outside. Four different assemblages have been established by microscopic observation within the coarse-grained zone; the phases are listed in the order of their formation.

Assemblage I: $\quad$ olivine $\rightarrow$ clinopyroxene $\rightarrow$ glass

Assemblage II: $\quad$ spinel $\rightarrow$ olivine $\rightarrow$ clinopyroxene $\rightarrow$ glass

Assemblage III: spinel $\rightarrow$ melilite $\rightarrow$ clinopyroxene $\rightarrow$ olivine $\rightarrow$ glass

Assemblage IV: spinel $\rightarrow$ melilite $\rightarrow$ olivine $\rightarrow$ glass.

Assemblages I and II are relatively rare. They were occasionally observed in coarse-grained zones of the slag, and their mineralogical composition is dominated by large laths or skeletal crystals of olivine (Fig. 2a) and small euhedral crystals of clinopyroxene. Assemblage III is the most common, typically present in the central part of slag casts. The crystal size of the two dominant phases (melilite, clinopyroxene) is larger than in assemblages I and II. This fact confirms the relatively slow crystallization in the center of the cast. Assemblage IV is dominated by large euhedral crystals of melilite and small laths of olivine (Fig. 2b). The absence of clinopyroxene in assemblage IV may be caused by a higher rate of cooling of the slag. The same assemblage was observed in quenched slag resulting from car-battery processing (Ettler et al. 2000).

The chemical and mineralogical compositions of the slags reflect the chemical composition of the ores and additives, together with the temperature and cooling rates of the melts. The lack of historical data concerning ore composition and smelting technologies used at Př́bram 100 to 150 years ago prevents direct correlations between the different assemblages and conditions of processing.

\section{Olivine}

Microscopic examination shows that olivine is the most abundant crystalline phase in the slag. On the basis of grain-size variations and crystal habit, olivine crystallized either early in assemblages I and II, or as the last silicate in assemblages III and IV, filling spaces between the earlier-crystallized silicates. Its habit is variable; skeletal "herring-bone" crystals and laths several hundred micrometers in length were observed in assemblages I and II (Fig. 2a), whereas small needles and very fine dendrites from several micrometers to tens of micrometers in size are present in assemblages III and IV (Figs. 2b, c). In transmitted light, the olivine crystals are colorless in plane light and display typical high interference-colors under crossed polars.

\section{Clinopyroxene}

Clinopyroxene occurs in assemblages I, II, and III found in the central parts of slag casts. Relatively slow rates of cooling allowed the formation of euhedral prismatic crystals. They may be present as phenocrysts up to several hundred micrometers across. The largest were observed in assemblage III, with generally smaller crystals in assemblages I and II. In transmitted light, they display a typical green color and a slight optical zoning.

\section{Melilite}

Melilite is abundant in assemblages III and IV, occurring either as irregular prisms with star or dendritic shapes or as euhedral phenocrysts (Fig. 2b). The melilite crystals can be hundreds of micrometers in size. They are colorless, without optical zoning, and have low interference-colors under crossed polars.

TABLE 1. PHASES OB\$ERVED R THE MET ALLLRGICAL SLAGS OF PRLBRAM

\begin{tabular}{|c|c|c|c|c|}
\hline Ciroup Niame & Composition & $\mathrm{slag}$ & $\begin{array}{l}\text { Mette } \\
\text { inal. }\end{array}$ & $\begin{array}{l}\text { massive } \\
\text { matte }\end{array}$ \\
\hline \multicolumn{5}{|l|}{ Siticates } \\
\hline Fayalile & $\mathrm{F}_{-2} \mathrm{SiO}_{4}$ & $* *$ & & \\
\hline Kirschsteitite & $\mathrm{CaFeSiO}_{4}$ & $1+4$ & & \\
\hline Hedenbergite & $\mathrm{CaFaSi}_{2} \mathrm{O}_{6}$ & $* *$ & & \\
\hline Mellibite series & $\mathrm{Ca} \mathrm{a}_{2}(\mathrm{Fe}, \mathrm{Mg}, \mathrm{Zn}, \mathrm{Al})\left(\mathrm{Si}_{\mathrm{r}} \mathrm{Al}\right)_{2} \mathrm{O}_{7}$ & $*$ & & \\
\hline \multicolumn{5}{|c|}{ 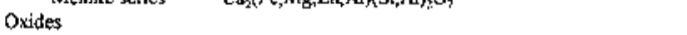 } \\
\hline $\begin{array}{l}\text { Spinel series } \\
\text { Sulfides }\end{array}$ & \multicolumn{3}{|c|}{ Sulfides } & \\
\hline Galena & $\mathrm{PbS}$ & & $*$ & ** \\
\hline Wurzite & $7 \pi 5$ & & • & 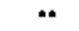 \\
\hline Borsite & $\mathrm{Cu}_{5} \mathrm{FeS}_{4}$ & & & $\bullet$ \\
\hline Digenite & $\mathrm{Cu}_{p_{\mathbf{z}}} \mathrm{S}_{3}$ & & & $*$ \\
\hline $\begin{array}{l}\text { Pyrtholite } \\
\text { Arsendides }\end{array}$ & $\mathrm{Fe}_{1 . x} \mathrm{~S}$ & & & ** \\
\hline Koutckite & $\mathrm{Cu}_{\mathrm{y}_{1}} \mathrm{As}_{2}$ & & & * \\
\hline Loblingire & TeAstis & & & * \\
\hline \multicolumn{5}{|l|}{ Metals } \\
\hline $\begin{array}{l}\text { Intermetallic } \\
\text { compounds }\end{array}$ & $A, F_{b}, S_{\Omega}, S_{b}, C_{u}, \mathrm{Ni}$ & & & $\bullet$ \\
\hline Puse metals & $\mathrm{Sb}, \mathrm{Cu}, \mathrm{Pb}$ & & • & $\omega$ \\
\hline
\end{tabular}

Description: *** abundent, ** cotthơn, * present. Matte incl. : inclusions of matte instag. 

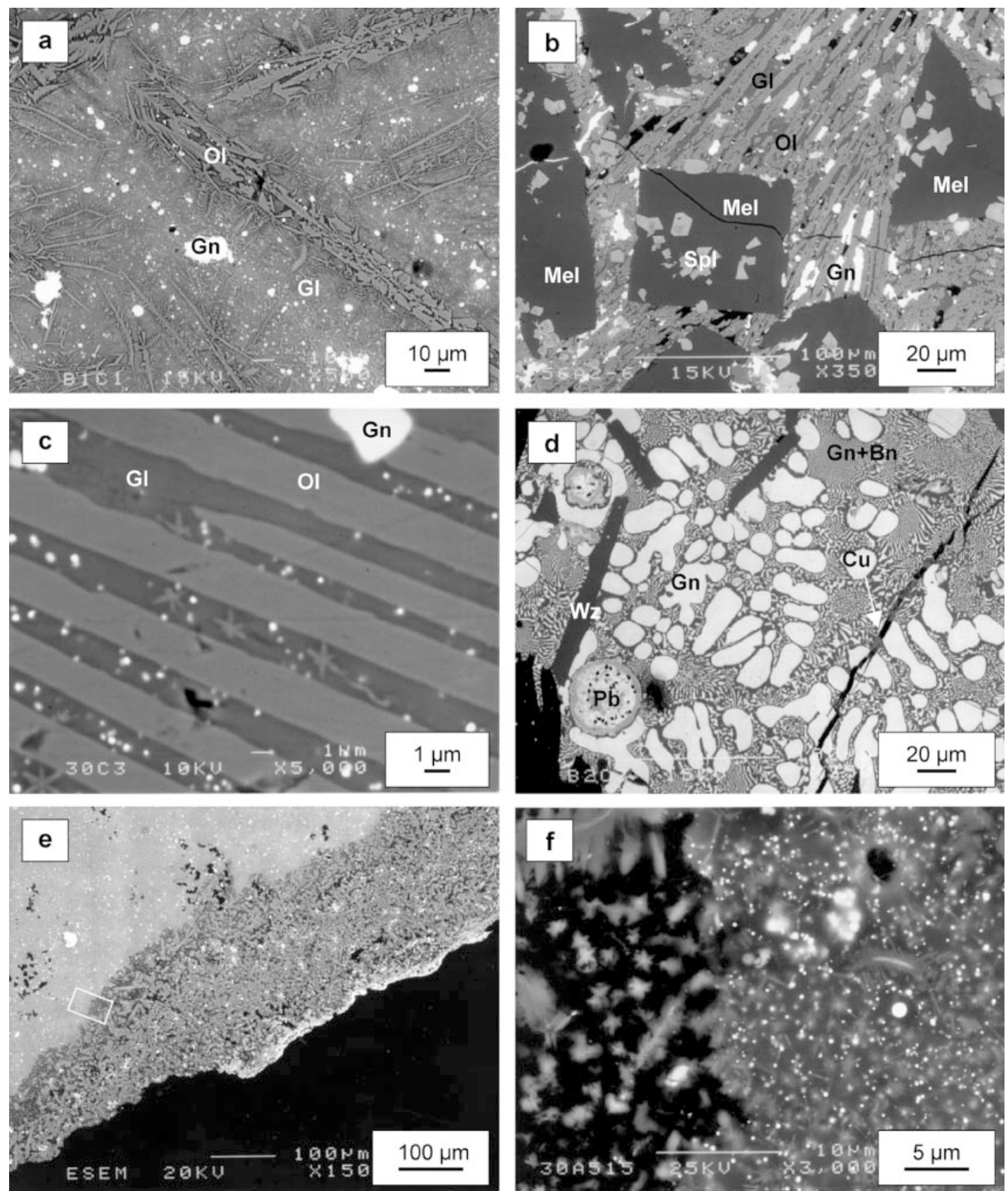

FIG. 2. Back-scattered electron images of Pb-metallurgical slag from Př́bram; a) dendritic olivine-group crystals (Ol) in amorphous glass (Gl) containing spherules of galena $(\mathrm{Gn})$; b) prismatic crystals of melilite (Mel) including euhedral crystals of zoned spinel ( $\mathrm{Spl}$ ), accompanied by long needles of olivine (Ol) in the matrix glass (Gl), with galena inclusions (Gn); c) needles of olivine $(\mathrm{Ol}) 3 \mu \mathrm{m}$ across in glass matrix $(\mathrm{Gl})$ containing submicrometric spherules of galena $(\mathrm{Gn})$ and star-shaped micrometric crystallites of olivine; d) symplectitic intergrowth of galena ( $\mathrm{Gn}$ ) and bornite (Bn) with needles of wurtzite (Wz), spherules composed of pure lead $(\mathrm{Pb})$, and a complex alloy of $\mathrm{Pb}, \mathrm{Sb}$, and $\mathrm{Sn}$, and grains of copper in the fissures $(\mathrm{Cu})$; e) "leached" weathering zone (dark field is epoxy; white-delimited zone is a blow-up corresponding to Fig. 2f); f) enlargement of the border of the "leached" zone between fresh and leached glass, with skeletal microcrystallites of olivine. 


\section{Spinel}

Where present, a spinel-group phase is amongst the first to crystallize from the silicate melt and generally forms cubic or octahedral crystals several micrometers across. Silicates nucleating simultaneously with the oxides usually enclose small crystals of spinel. Optical zoning in reflected light is a typical feature, with a dark gray core and a significantly brighter rim, with the possibility of several different zones in the same crystal. In assemblage II, spinel is a trace phase, but it is more abundant in assemblages III and IV.

\section{Glass}

Opaque glass forms a black interstitial matrix hosting both silicate and oxide crystals. Surface (transparent) glass is localized in the chilled borders of slag casts and results from a rapid quenching of initial slag melt; it is usually colorless, commonly with yellowish or brownish stains. It commonly is banded, with randomly oriented acicular microcrystallites of olivine and melilite present to depths of tens of micrometers below the cast surface. Both types of glass contain small inclusions of sulfide, generally submicrometric (Fig. 2c), owing to the immiscibility of sulfide and silicate liquids (Gasser $e t$ al. 1996). Such spherules are difficult to analyze by electron microprobe but, from their qualitative analysis using EDS/SEM, they appear to be formed of galena $(\mathrm{PbS})$, wurtzite $(\mathrm{ZnS})$ or metallic lead $(\mathrm{Pb})$. Larger droplets, as well as massive mattes, exhibit more complex compositions ranging from various sulfides to arsenides and various intermetallic compounds (Table 1). These phases commonly display complex symplectitic intergrowths of bornite and galena (Fig. 2d) or chalcocite and galena.

We used X-ray diffraction (XRD) analyses to identify the following common phases in the silicate slag: spinel, melilite, Ca-rich olivine (monticellite or kirschsteinite), olivine (fayalite), clinopyroxene, wurtzite and galena.

\section{Composition of the Phases}

\section{Olivine-group phases}

Although showing a widely variable chemical composition, olivine-group phases in the slag are here sim-

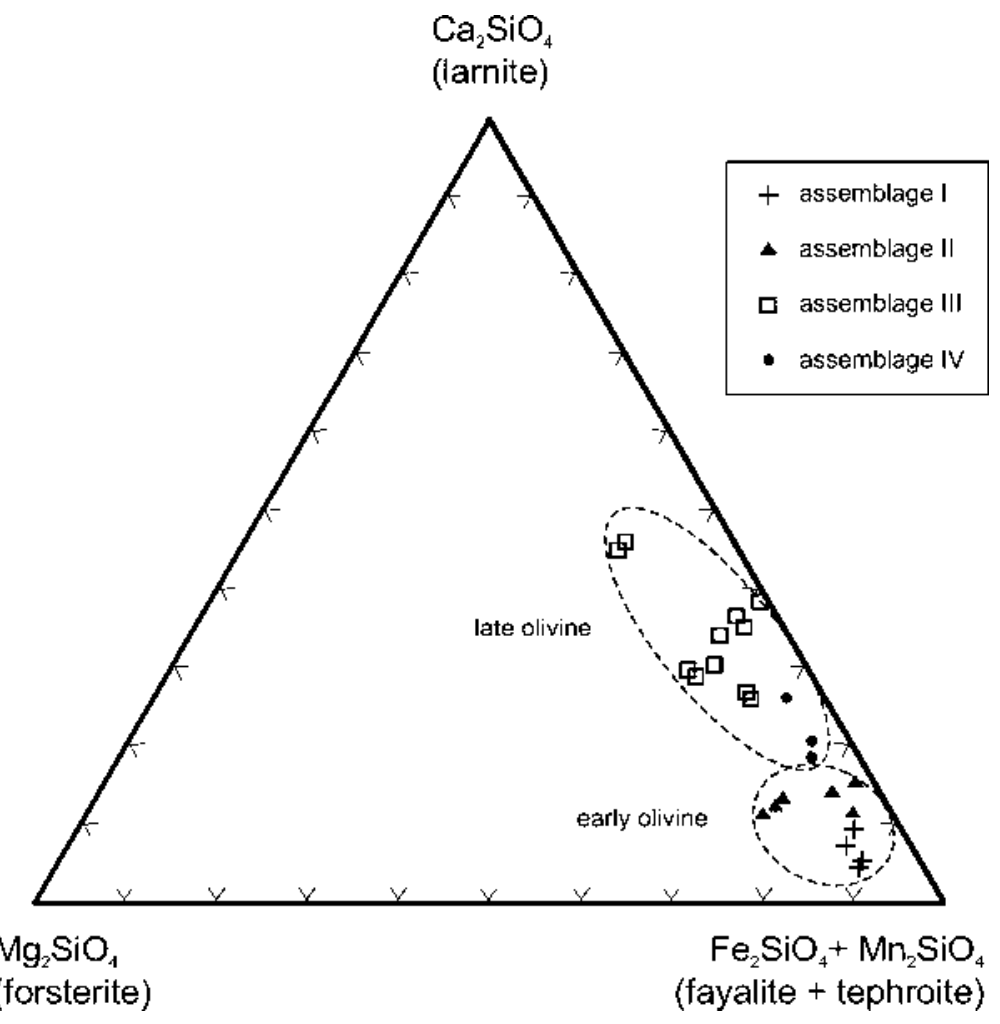

FIG. 3. Position of olivine compositions in the larnite - forsterite - (fayalite + tephroite) diagram $(n=26)$. 
ply called "olivine". Electron-microprobe analyses show that the olivine ranges in chemical composition from quasi-pure fayalite $\left(\mathrm{Fe}_{2} \mathrm{SiO}_{4}\right)$ to kirschsteinite $(\mathrm{CaFe}$ $\mathrm{SiO}_{4}$ ) and may contain up to $27.48 \mathrm{wt} \% \mathrm{CaO}$ (Fig. 3, Table 2). Two distinct compositional ranges tend to occur in different assemblages. In assemblages I and II, where an olivine is the early-crystallizing silicate, the highest calcium content is $8 \mathrm{wt} \% \mathrm{CaO}$ (anal. 1, 2, and 3, Table 2). In contrast, assemblages III and IV show fine laths and dendrites that crystallized at the end of the sequence. These are Ca-enriched, containing between 10 and $27 \mathrm{wt} \% \mathrm{CaO}$. In the case of assemblage III, the composition of the olivine depends upon its proportion in the assemblage and on the size of previously crystallized phases (melilite, clinopyroxene). A slower cool- ing of the melt allows the formation of larger crystals of early silicates (melilite and clinopyroxene) followed by the crystallization of small laths of Ca-poorer olivine (anal. 5, Table 2). However, a slightly faster cooling results in the formation of smaller crystals of melilite and clinopyroxene, and the subsequently crystallizing olivine is Ca-rich and fills more of the space (anal. 4, Table 2).

The composition of the olivine-group phases may be expressed as three end-members: larnite $\left(\mathrm{Ca}_{2} \mathrm{SiO}_{4}\right)$, forsterite $\left(\mathrm{Mg}_{2} \mathrm{SiO}_{4}\right)$, and fayalite $\left(\mathrm{Fe}_{2} \mathrm{SiO}_{4}\right)+$ tephroite $\left(\mathrm{Mn}_{2} \mathrm{SiO}_{4}\right)$ (Fig. 3). In terms of these end-members, the most $\mathrm{Ca}$-rich olivine can be expressed as $\mathrm{La}_{46} \mathrm{Fo}_{13}$ $(\mathrm{Fa}+\mathrm{Te})_{41}$ and corresponds approximately to kirschsteinite (anal. 4, Table 2). Both early and late batches of

TABLE 2. REPRESEXTATTYE COMPOSITION OF OLIVINE AND CLINOPYROXENE IN THE MET ALLURGICAL SLAGS OF PRİBRAM

\begin{tabular}{|c|c|c|c|c|c|c|c|c|c|c|c|c|}
\hline \multirow[b]{3}{*}{ assemblage } & \multicolumn{6}{|c|}{ divine } & & \multicolumn{5}{|c|}{ clinophroxene } \\
\hline & \multirow{2}{*}{$\begin{array}{l}1 \\
1\end{array}$} & \multirow{2}{*}{$\frac{2}{1}$} & \multirow{2}{*}{$\begin{array}{l}3 \\
\text { II }\end{array}$} & \multirow{2}{*}{$\begin{array}{c}4 \\
\text { III }\end{array}$} & \multirow{2}{*}{$\begin{array}{c}5 \\
\text { JII }\end{array}$} & \multirow{2}{*}{$\begin{array}{c}6 \\
I V\end{array}$} & & \multirow{2}{*}{ I } & \multirow{2}{*}{$\begin{array}{l}\mathrm{g} \\
\mathrm{II}\end{array}$} & \multirow{2}{*}{$\begin{array}{c}9 \\
\pi I\end{array}$} & \multirow{2}{*}{$\begin{array}{l}10 \\
\text { IIl }\end{array}$} & \multirow{2}{*}{$\begin{array}{l}11 \\
\text { III }\end{array}$} \\
\hline & & & & & & & & & & & & \\
\hline $\mathrm{SiO}_{2}$ & 29.79 & 29.66 & 30.03 & 32.89 & 3115 & 30.52 & $\mathrm{SiO}_{1} \mathrm{M} \%$ & 41.87 & 39.87 & 40.07 & 43.30 & 43.34 \\
\hline $\mathrm{TiO}_{2}$ & 0.04 & 0.04 & 0.00 & 0.03 & 0.00 & 0.06 & $\mathrm{TiO}_{2}$ & 0.25 & 0.59 & 1.03 & 0.39 & 0,55 \\
\hline $\mathrm{Al}_{2} \mathrm{O}_{5}$ & 0.01 & 0,02 & 0.74 & 0.49 & 0.26 & 0.06 & $\mathrm{~A}_{2} \mathrm{O}_{1}$ & 6.12 & 10.19 & 11.20 & 4.73 & 8.06 \\
\hline $\mathrm{FeO}$ & 54.19 & 55,57 & 51.13 & 27.57 & 41.23 & 47.52 & $\mathrm{FeO}$ & 26.14 & 22.67 & $19.91=$ & 23.50 & 20.68 \\
\hline $\mathrm{MnO}$ & 3.22 & 4.42 & 2.13 & 361 & 5.91 & 1.48 & $M \cap D$ & 0.92 & 0.62 & 1.40 & 1.80 & 1.39 \\
\hline $\mathrm{MgO}$ & $2.9]$ & 2.28 & 0.85 & 5.33 & 3.68 & 1.68 & $\mathrm{MgO}$ & 0.65 & 0.19 & 2.41 & 1.50 & 2.06 \\
\hline $\mathrm{CaO}$ & 3.87 & 2.77 & 8.0 & 27.48 & 15.38 & 14.49 & $\mathrm{CaO}$ & 21.71 & 2. 492 & 22.62 & 20.59 & 22.29 \\
\hline $\mathrm{Na}_{2} \mathrm{O}$ & 0.10 & 0,00 & 0.27 & 0.08 & 0.00 & 016 & $\mathrm{Ne}_{2} \mathrm{O}$ & 009 & 0.28 & 0.03 & 0.13 & 0.12 \\
\hline $\mathbf{K}, \mathbf{O}$ & 0.00 & 0.00 & 0.14 & 0.06 & 0,22 & 0.03 & $\mathrm{~K} \mathrm{O}$ & 0.00 & 0.26 & 0.01 & 0.00 & 0.03 \\
\hline $\mathrm{Cr}_{2} \mathrm{O}_{3}$ & 0.03 & 0.01 & 0.01 & 0.015 & 0.00 & 0.00 & $P_{2} Q_{5}$ & 0.00 & 0.60 & 0.00 & 0.43 & 023 \\
\hline $\mathrm{PbO}$ & 0.11 & 000 & 0.11 & 0.02 & 0.05 & 0.18 & $\mathrm{Cr}_{2} \mathrm{O}_{3}$ & 0.00 & 0.00 & 0.00 & 000 & 0.00 \\
\hline $\mathrm{ZnO}$ & 5.82 & 4.34 & 6.28 & 2.32 & 1.98 & 3.80 & $\mathrm{PbO}$ & 0.08 & 0.16 & 0,00 & 0.00 & 0.20 \\
\hline $\mathrm{SO}_{3}$ & 0.02 & 0.02 & 0.00 & 0.11 & 0.07 & 0.08 & NiO & 0.00 & 000 & 0.00 & 0.09 & 0,00 \\
\hline \multirow[t]{3}{*}{ total } & 100.09 & 99.11 & 99.7616 & 100.08 & 99941 & 100,06 & $\mathrm{ZnO}$ & 2.71 & 2.82 & 1.23 & 3.12 & 1.65 \\
\hline & & & & & & & $\mathrm{SO}_{3}$ & 0,00 & 0.07 & 0.00 & 0.69 & 0,04 \\
\hline & trobers of & fetoms o & on the ba & asis of 4 & 40 & & tota: & 100.54 & 99.195 & 98.901 & 100.26 .10 & 100.61 \\
\hline si apju & 0.989 & 0.996 & 1.008 & 1.004 & 0.995 & 0.904 & \multicolumn{6}{|c|}{ numbers of atoms on the basis of 60} \\
\hline Fe & 1.505 & 1.561 & 1.435 & 0. 706 & 1.101 & 1.294 & & & & & & \\
\hline$M n$ & 0.091 & 0.126 & 0.060 & 0.093 & 0.160 & 0.041 & Si apftr & 1.746 & 1,664 & 1.633 & 1.810 & $1.75]$ \\
\hline $\mathrm{Mg}$ & 0.144 & 0.114 & 0.043 & 0.243 & 0.175 & 0,082 & $\mathrm{rAl}_{\mathrm{Al}}$ & 0.254 & 40.336 & 0.367 & 0.190 & 0.249 \\
\hline $\mathrm{Ca}$ & 0.138 & 0.100 & 0.250 & 0.898 & 0.526 & 0.500 & $m_{\mathrm{Al}}$ & 0.047 & 0.165 & 0.151 & 0.043 & 0.135 \\
\hline $\mathbf{C r}$ & 0001 & 0000 & 0.000 & 0.000 & 0,000 & 0.000 & $\mathrm{Ti}$ & $0.00 \%$ & 0.018 & 0031 & 10.012 & 0.017 \\
\hline Ni & a.cono & 0.000 & 0.000 & 0.000 & 0.000 & 0.000 & $\mathrm{Fe}$ & 0.912 & 20.701 & 0.044 & 40.822 & 0.699 \\
\hline \multirow[t]{4}{*}{$\mathrm{Zn}_{\mathrm{n}}$} & 0.143 & 0.108 & 0.156 & 0.052 & 0.047 & 0.091 & $\mathrm{Mr}$ & 0.073 & 30.022 & 0.048 & 0.064 & 0.048 \\
\hline & & & & & & & $\mathrm{Mg}$ & 0.040 & 0.012 & 0.147 & 0.094 & 0.124 \\
\hline & linates in & $\mathrm{La}-\mathrm{Fa}-\mathrm{C}$ & $(\mathrm{Fa}-\mathrm{T}$ & c) space & e $[$ mol. $\%$ & & $Z \mathrm{n}$ & 0.084 & 10.087 & 0.037 & 0.095 & 0.049 \\
\hline & & & & & & & $\mathrm{Cr}$ & $0.000]$ & 0.000 & 0,000 & 0.000 & 0.000 \\
\hline $\mathrm{La}$ & 7.3 & 5,2 & 15.9 & 46.3 & 26.8 & 26.3 & $\mathrm{Ca}$ & 0.970 & 0.951 & 0,988 & 0.922 & 0.965 \\
\hline Fo & 7.7 & 0.0 & 2.3 & 125 & 8.9 & 4.2 & $\mathrm{Na}$ & 0.007 & 0.022 & 0.002 & 0.011 & 0.009 \\
\hline \multirow[t]{9}{*}{$F_{d} \div T_{t}$} & 850 & 88.7 & 81.8 & 412 & 64.2 & 69.4 & & & & & & \\
\hline & & & & & & & \multicolumn{6}{|c|}{ coordinates in Wo-cEn-cFs space [mol. $\%]$} \\
\hline & & & & & & & Wo & 49.6 & 53.85 & 54.1 & 4855 & 52.6 \\
\hline & & & & & & & $\mathrm{cEn}$ & 2.1 & 0.6 & 80 & 49 & 6.8 \\
\hline & & & & & & & $\mathrm{cFs}$ & 48.3 & 45.53 & 37.9 & 46.64 & 40.7 \\
\hline & & & & & & & \multicolumn{6}{|c|}{ coordjnates in ( $\left.\mathrm{D}_{1}^{\prime}+\mathrm{Hd}_{\mathrm{d}}\right)-\mathrm{Jh}-\mathrm{Pe}$ space [tmol.\%] } \\
\hline & & & & & & & $D_{i}+H_{d}$ & 80.1 & 88.19 & 90.3 & 85.18 & 89.5 \\
\hline & & & & & & & Л & 3.1 & 2.4 & 5.5 & 59 & 5.2 \\
\hline & & & & & & & $\mathrm{Pe}$ & 7.8 & 9.5 & 42 & 9.0 & 5.3 \\
\hline
\end{tabular}

Symbols used; La lamite, Fo forsterile. Fa fayalite, Te tephroite, Wo wellastonite, cEn clinoenstatite, cts dinoferiosilite. $D^{j}$ dispside, Hd hedenbergite, Jh johannserjite, Pe petedurrite, apfs atoms per formula unit. The compositions were obtained by electron-micopopobe andysis. 
olivine are Zn-bearing (average concentration: $4.29 \mathrm{wt} \%$ $\mathrm{ZnO}$ ), but early crystals of olivine are slightly enriched, containing up to $6.28 \mathrm{wt} \% \mathrm{ZnO}$. These high concentrations support the suggestion by Chaudhuri \& Newesely (1993) that Zn (ionic radius $0.74 \AA$ ) can enter into octahedral sites of the structure and substitute for $\mathrm{Fe}^{2+}$ (ionic radius $0.76 \AA$ ). The solid-solution series $\mathrm{Fe}_{2} \mathrm{SiO}_{4}$ (fayalite) $-\mathrm{Zn}_{2} \mathrm{SiO}_{4}$ (willemite) is known to be continuous up to $17 \mathrm{~mol} \% \mathrm{Zn}(13.37 \mathrm{wt} \% \mathrm{ZnO}$, Ericsson \& Filippidis 1986, Kucha et al. 1996). The analyzed crystals also contain higher amounts of Mn than other silicates present in the slag (up to $5.91 \mathrm{wt} \% \mathrm{MnO}$, anal. 5, Table 2). The $\mathrm{Pb}$ concentrations are low, up to $0.18 \mathrm{wt} \%$ $\mathrm{PbO}$, with an average value of $0.06 \mathrm{wt} \%$.

\section{Clinopyroxene}

The chemical composition of the clinopyroxene is variable. Ca contents are relatively constant (20.59$22.62 \mathrm{wt} \% \mathrm{CaO}$ ), but concentrations of other elements show significant scatter; $\mathrm{Fe}$ (18.91-26.14 wt\% FeO), Al (4.73-11.20 wt $\left.\% \mathrm{Al}_{2} \mathrm{O}_{3}\right)$ and $\mathrm{Mg}(0.19-2.41 \mathrm{wt} \%$ $\mathrm{MgO}$ ). Results of electron-microprobe analyses were plotted in terms of wollastonite $\left(\mathrm{Ca}_{2} \mathrm{Si}_{2} \mathrm{O}_{6}\right)$ - clinoensta- tite $\left(\mathrm{Mg}_{2} \mathrm{Si}_{2} \mathrm{O}_{6}\right)$ - clinoferrosilite $\left(\mathrm{Fe}_{2} \mathrm{Si}_{2} \mathrm{O}_{6}\right)$ (Morimoto 1989) and correspond closely to a hedenbergite composition, although generally enriched in Ca (Fig. 4). In order to conform to the classification system of pyroxenes, the normalization used for the above-mentioned plot was $\mathrm{Ca}+\mathrm{Mg}+\Sigma \mathrm{Fe}$, where $\Sigma \mathrm{Fe}=\mathrm{Fe}^{2+}+$ $\mathrm{Fe}^{3+}+\mathrm{Mn}$ (Morimoto 1989). Analytical profiles through a clinopyroxene crystal confirmed a slight zoning in $\mathrm{Si}$, $\mathrm{Al}, \mathrm{Mg}$ and $\mathrm{Fe}$ : the border is enriched in $\mathrm{Fe}$ and $\mathrm{Al}$, and depleted in $\mathrm{Si}$ and $\mathrm{Mg}$. The maximum $\mathrm{Pb}$ concentration in clinopyroxene is $0.20 \mathrm{wt} \% \mathrm{PbO}$. The amount of $\mathrm{Zn}$ is significantly higher, up to $3.12 \mathrm{wt} \% \mathrm{ZnO}$ (i.e., 0.10 cations per formula unit), corresponding to zincian hedenbergite (Morimoto 1989). The average amount of $\mathrm{Zn}$ in clinopyroxenes is $2.26 \mathrm{wt} \% \mathrm{ZnO}$. In order to classify Zn-bearing clinopyroxenes, Essene \& Peacor (1987) used a composition diagram with three end-members: diopside + hedenbergite $\left[\mathrm{Ca}(\mathrm{Mg}, \mathrm{Fe}) \mathrm{Si}_{2} \mathrm{O}_{6}\right]$, johannsenite $\left(\mathrm{CaMnSi}_{2} \mathrm{O}_{6}\right)$ and petedunnite $\left(\mathrm{CaZnSi}_{2} \mathrm{O}_{6}\right)$. In terms of this classification, the most $\mathrm{Zn}$-enriched composition of clinopyroxene can be expressed as $(\mathrm{Di}+\mathrm{Hd})_{85}$ $\mathrm{Jh}_{6} \mathrm{Pe}_{9}$ (anal. 10, Table 2). Concentrations of zinc in clinopyroxene appear to be independent of the phase assemblage.

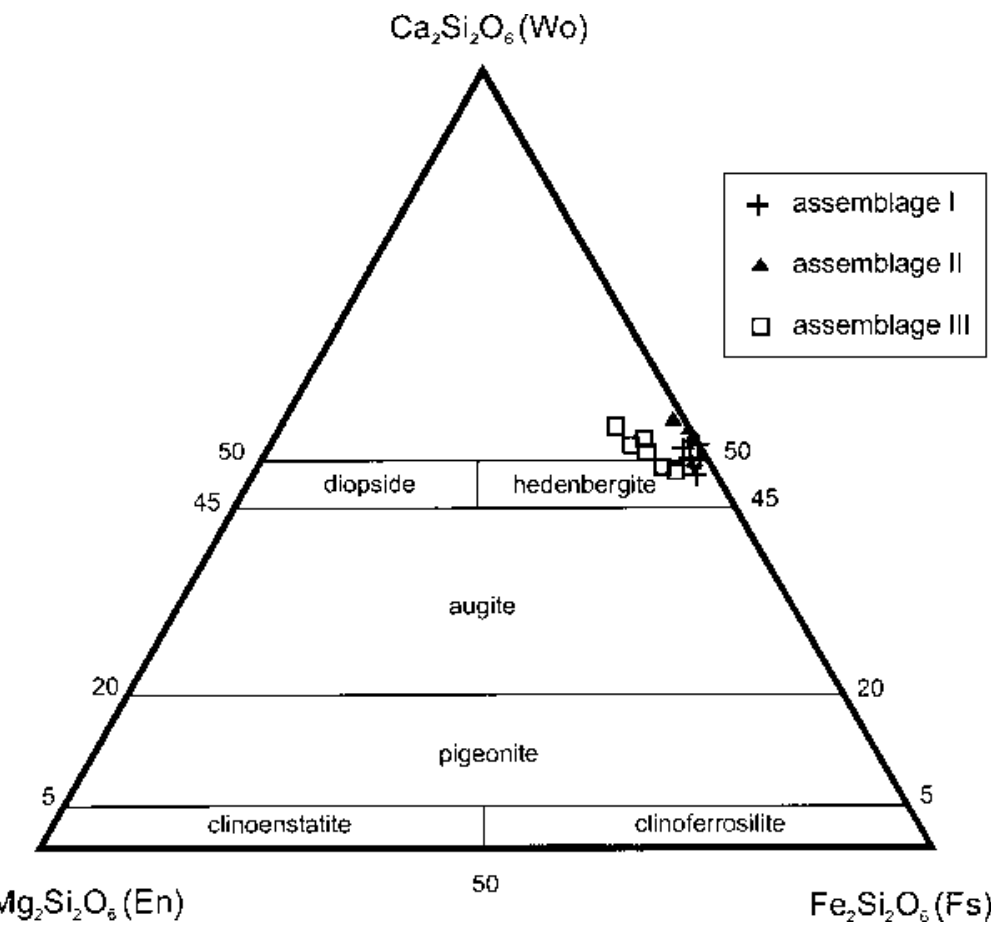

FIG. 4. Position of clinopyroxene compositions in the wollastonite - clinoenstatite clinoferrosilite diagram $(n=14)$. 


\section{Melilite}

The composition of the melilite varies considerably (Table 3), and the major elements fall within the following ranges: $\mathrm{Ca}(34.11-37.28 \mathrm{wt} \% \mathrm{CaO}), \mathrm{Na}(0.32-$ 2.36 wt $\left.\% \mathrm{Na}_{2} \mathrm{O}\right), \mathrm{Fe}(7.51-9.00 \mathrm{wt} \% \mathrm{FeO}), \mathrm{Al}$ (3.32-5.09 $\left.\mathrm{wt} \% \mathrm{Al}_{2} \mathrm{O}_{3}\right)$ and $\mathrm{Mg}(1.82-4.45 \mathrm{wt} \% \mathrm{MgO})$. In addition, $\mathrm{Zn}$ is a major component in some cases; up to $10.51 \mathrm{wt} \% \mathrm{ZnO}$ (average $6.95 \mathrm{wt} \% \mathrm{ZnO}$ ) was determined by electron-microprobe analysis. Slightly higher concentrations of zinc were observed in melilite from assemblage IV (anal. 16, 17, 18, Table 3). Lead also is present in significant amounts, with up to $0.35 \mathrm{wt} \% \mathrm{PbO}$ (anal. 18, Table 3). The melilite compositions correspond to a solid solution of several end-members: minor amounts of soda-melilite $\left(\mathrm{CaNaAlSi}_{2} \mathrm{O}_{7} \leq 18.0\right.$ mol.\%) and gehlenite $\left(\mathrm{Ca}_{2} \mathrm{Al}_{2} \mathrm{SiO}_{7} \leq 10.2 \mathrm{~mol} . \%\right)$, with higher amounts of åkermanite $\left(\mathrm{CaMgSi}_{2} \mathrm{O}_{7} \leq 33.0\right.$ mol.\%), iron-substituted åkermanite $\left(\mathrm{CaFeSi}_{2} \mathrm{O}_{7} \leq 36.5\right.$ mol.\%) and hardystonite $\left(\mathrm{CaZnSi}_{2} \mathrm{O}_{7} \leq 38.5 \mathrm{~mol} . \%\right)$.

\section{Spinel-group phases}

A spinel-group phase is the only oxide observed in the slag. Although minor in proportion, this phase is significant regarding the heavy metal behavior in the slag owing to its high $\mathrm{Zn}$ concentrations and to the presence of Cr. Its chemical composition is rather complex, but can be expressed by the common formula $(\mathrm{Zn}, \mathrm{Mg}, \mathrm{Fe})(\mathrm{Fe}, \mathrm{Al}, \mathrm{Cr}, \mathrm{Ti}, \mathrm{Si})_{2} \mathrm{O}_{4}$ (Table 3). Concentrations of elemental iron obtained by EMPA were recalculated to $\mathrm{Fe}^{2+}$ and $\mathrm{Fe}^{3+}$ according to charge balance. The spinel grains contain important amounts of $\mathrm{Fe}^{3+}$ (up to 48.44 wt $\% \mathrm{Fe}_{2} \mathrm{O}_{3}$ ), $\mathrm{Fe}^{2+}$ (up to 30.86 wt $\%$ of $\mathrm{FeO}$ ), $\mathrm{Al}$ (up to 38.99 wt $\% \mathrm{Al}_{2} \mathrm{O}_{3}$ ) and $\mathrm{Zn}$ (up to $19.91 \mathrm{wt} \%$ $\mathrm{ZnO}$ ). Their bulk composition indicates that they belong to the hercynite-gahnite and franklinite-magnetite families. The concentrations of $\mathrm{Cr}$ and $\mathrm{Mg}$ are rather low, but may reach locally nearly $7 \mathrm{wt} \% \mathrm{Cr}_{2} \mathrm{O}_{3}$ and $3 \mathrm{wt} \%$ $\mathrm{MgO}$, respectively. In back-scattered electron mode, the spinel grains show optical zoning, which reflects a

TABLE 3. REPRESENTATIVE COMPOSITION OF MEL LLITE AND SPINEL

IN THE MFTALLURGICAI, SLAGS OF PRIBRAM

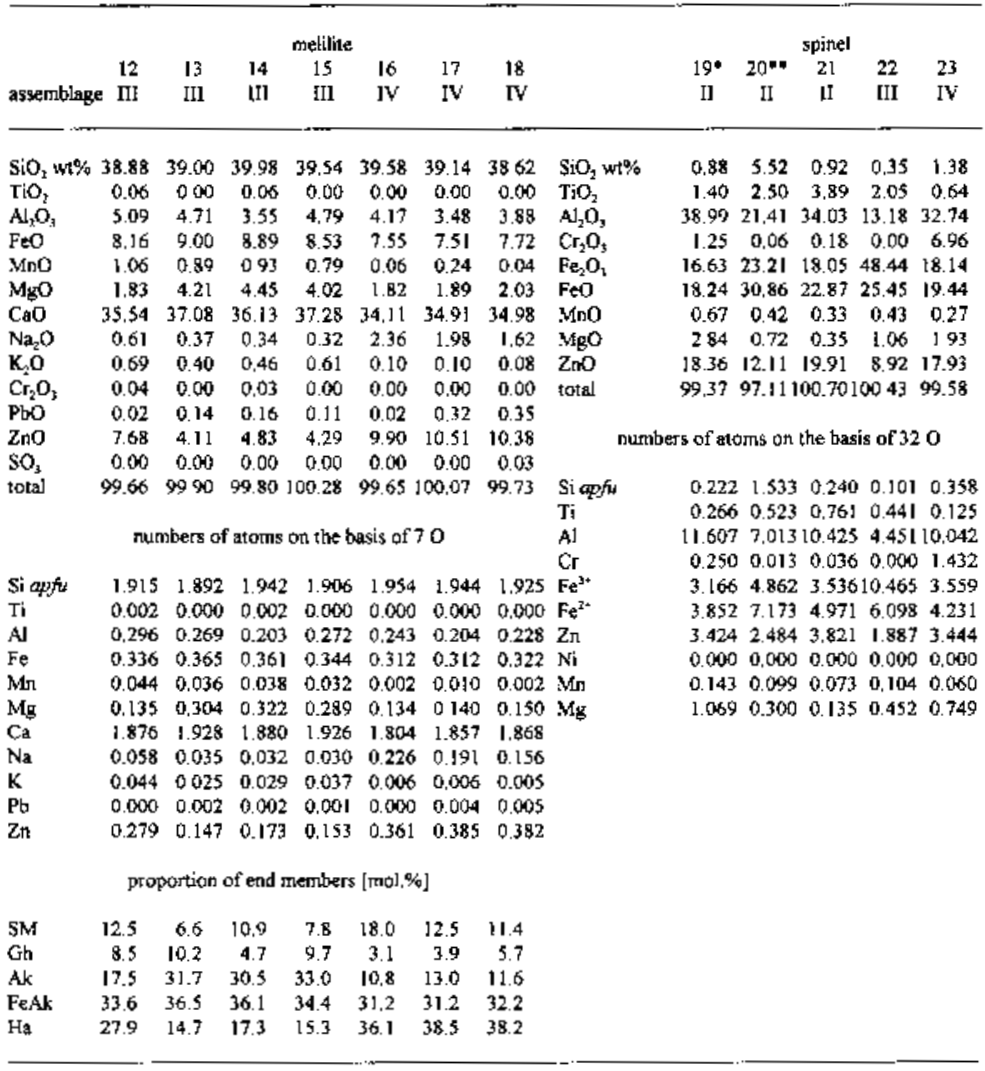

Symbols: SM soda melilite, Gh gehlenite, Ak akermaute, FeAk iron-substhuted lkermanite, Ha hardystonite, aphir hions per formula urit. The compositions weto oblaited by electron-microprobe analysis. * spirel core (darker). +* spinel rim (brighter) 
chemical zoning (Fig. 2b); the darker internal parts are enriched in $\mathrm{Zn}, \mathrm{Mg}, \mathrm{Cr}$ and $\mathrm{Al}$, and the brighter external parts are Fe-rich.

\section{Glass}

Electron-microprobe analyses show that, like the other silicate phases, the glass is $\mathrm{Fe}$ - and Ca-rich (Table $4)$. The major oxide components vary widely in proportion for both transparent and opaque glass: $\mathrm{SiO}_{2}(32.81-$ $42.52 \%), \mathrm{FeO}(11.40-42.52 \%), \mathrm{CaO}(9.72-33.08 \%)$, $\mathrm{Al}_{2} \mathrm{O}_{3}(2.56-14.10 \%), \mathrm{MnO}(0.05-5.43 \%), \mathrm{MgO}(0.01-$ $3.07 \%), \mathrm{Na}_{2} \mathrm{O}(0.12-2.75 \%)$ and $\mathrm{K}_{2} \mathrm{O}(0.15-3.50 \%)$. Typical glass also exhibits elevated concentrations of $\mathrm{Zn}(\leq 9.80 \mathrm{wt} \% \mathrm{ZnO}$, average $5.00 \mathrm{wt} \% \mathrm{ZnO})$ (anal. 29, Table 4). In comparison with the crystalline silicates, the glasses have higher $\mathrm{Pb}$ (up to $3.72 \mathrm{wt} \% \mathrm{PbO}$ ) (anal. 27, Table 4). There are slight differences between the average chemical compositions of matrix (opaque) and surface (transparent) glass. Matrix glass is slightly depleted in $\mathrm{Fe}, \mathrm{Ca}$, and $\mathrm{Mn}$ and enriched in $\mathrm{Na}, \mathrm{K}$ and $\mathrm{Pb}$ relative to surface glass, as shown by the following averages (matrix/surface glass): 19.97/23.45 wt $\% \mathrm{FeO}$, 16.66/21.28 wt $\% \mathrm{CaO}, 1.45 / 2.41 \mathrm{wt} \% \mathrm{MnO}, 2.35 / 0.57$ wt $\% \mathrm{PbO}, 0.89 / 0.87 \mathrm{wt} \% \mathrm{Na}_{2} \mathrm{O}$ and $1.69 / 0.72 \mathrm{wt} \% \mathrm{~K}_{2} \mathrm{O}$ (Table 4). Similarly, in terms of the ternary system $\mathrm{FeO}-$ CaO-SiO 2 (Fig. 5, after Eusden et al. 1999), matrix and surface glasses are clustered into two slightly different populations. Interestingly, there is only a small difference in $\mathrm{Zn}$ contents between matrix and surface glasses (Table 4). The chemical composition of surface glass, representing a superficial quenched layer, corresponds to a chemical composition of initial slag melt. In the ternary liquidus diagram (Fig. 5), the position of sur- face glass reveals the melting temperature of slag, i.e., between $1150^{\circ} \mathrm{C}$ and $1450^{\circ} \mathrm{C}$. Low analytical totals (commonly about $97 \mathrm{wt} \%$ ) may be due to the presence or $\mathrm{H}_{2} \mathrm{O}$ of trivalent iron (or both) in the glass structure.

\section{Features Attributed to Weathering}

All the thin and polished sections prepared from the external parts of the slag casts were systematically investigated for weathering effects, but only two types were observed; leaching of glass and the development of secondary phases.

The leaching of glass at the surface of the cast ("leached" zone, Fig. 2e) is the most frequently observed feature attributed to weathering. The glass is leached to a depth of $200 \mu \mathrm{m}$, and there is a distinct change in its chemical composition. The leaching leaves a skeleton of silicate microcrystallites, mainly olivine, as shown by the SEM observation (Fig. 2f). X-ray maps of the zone shown in Figure 2e were prepared to show the effects of leaching on characteristic elements (Fig. 6). As expected, there is a regular decrease in alkali $(\mathrm{K})$ concentration toward the surface, with $\mathrm{Ca}, \mathrm{Fe}, \mathrm{Zn}$ and $\mathrm{S}$ showing the same trend (Fig. 6). An X-ray map for Na was omitted owing to the very low concentration of sodium in glass. The decrease in sulfur is probably due to the weathering of submicrometric droplets of sulfides disseminated throughout the glass. SEM observations (Fig. 2f) also confirm the dissolution of Pb-rich droplets of submicrometric size, although the X-ray map shows possible local enrichment in $\mathrm{Pb}$ (Fig. 6). Semiquantitative SEM/EDS analyses performed on both fresh and "weathered" glass confirm the leaching of $\mathrm{Na}$, $\mathrm{K}, \mathrm{Fe}, \mathrm{Zn}$ and $\mathrm{Ca}$. The altered glass shows a relative

TAELE 4 REPRESENTATIVE COMPOSITION OF GIASS IN THE METALLURGICAL SLAGS OF PRIBRAM

\begin{tabular}{|c|c|c|c|c|c|c|c|c|c|c|}
\hline & \multicolumn{4}{|c|}{ matrix glass } & \multicolumn{4}{|c|}{ surface glass } & \multicolumn{2}{|c|}{ arerage of all } \\
\hline & 24 & 25 & 26 & 27 & 28 & 29 & 30 & $3 \mathbf{I}$ & $r=7$ & $\pi=9$ \\
\hline $\mathrm{TiO}_{2} w \mathrm{t} \%$ & 0,43 & 0.30 & 0.23 & 0.52 & 0.41 & 0.13 & 006 & 0.22 & 0.37 & 0.24 \\
\hline $\mathrm{SjO}_{2}$ & 39,69 & 39.66 & 39.62 & 37.95 & 33.11 & 37.38 & 33.77 & 3517 & 38.52 & 35.42 \\
\hline $\mathrm{Al}_{2} \mathrm{O}_{3}$ & 11,33 & 12.55 & 13.40 & 7.96 & 5.83 & 4.66 & 426 & 3.32 & 9.95 & 5.43 \\
\hline FeO & 21.49 & 15.50 & 16.21 & $20 \mathrm{BT}$ & 32.30 & 11.40 & 36.00 & 2301 & 19.97 & 23.45 \\
\hline $\mathrm{M} \rightarrow \mathrm{O}$ & 0,53 & 0,67 & 0.60 & 1.43 & 5.43 & 0.05 & 1.27 & 2.65 & 1.45 & $2.4 !$ \\
\hline $\mathrm{MgO}$ & 0,1 & 0.04 & 001 & 0.21 & 1.08 & 1.48 & 1,22 & 2.97 & 0.35 & 1.89 \\
\hline $\mathrm{CaO}$ & 20.2 & 14.84 & 972 & 17.81 & 13.40 & 33.08 & 11.30 & 23.75 & 16.60 & 21.81 \\
\hline $\mathrm{Ne}_{3} \mathrm{O}$ & 0.44 & 1.62 & 2.27 & 0.19 & 0.28 & 205 & 1.84 & 0.15 & 0.89 & 0.87 \\
\hline $\mathrm{K}_{2} \mathbf{O}$ & 0.83 & 2.01 & 3.39 & 0.94 & 0.70 & 0.15 & 1.21 & 0,39 & 1.69 & 0.72 \\
\hline $\mathrm{Cr}_{2} \mathrm{O}_{2}$ & 0.00 & 0.00 & 000 & 0.05 & 0.05 & 0.00 & 0.04 & 0.00 & 0.01 & 0.03 \\
\hline $\mathrm{PbO}$ & 0.26 & 3.34 & 2.98 & 3,72 & 0.09 & 0.29 & 0.96 & 0.63 & 2.35 & 0.57 \\
\hline $\mathrm{ZnO}$ & 2.59 & 6.27 & 800 & 4.62 & 436 & 9.80 & 4.80 & 3.41 & 4.74 & 5.20 \\
\hline $\mathrm{SO}_{3}$ & 0.00 & 0.47 & 0.53 & 0.88 & 300 & 0.06 & 1.51 & 1.85 & 0.60 & 1.80 \\
\hline $\mathrm{As}_{2} \mathrm{O}_{1}$ & 0.00 & 0.08 & 0.15 & 0,00 & 0.00 & 0.00 & 0.00 & 0,00 & 0.04 & 0.00 \\
\hline total & 97.81 & 97.33 & 97.20 & 97.14 & 100.04 & 100.53 & 98.25 & 99.95 & 97.61 & 59.82 \\
\hline
\end{tabular}

The comfositions were obtained by electron-micropsobe analysis. 


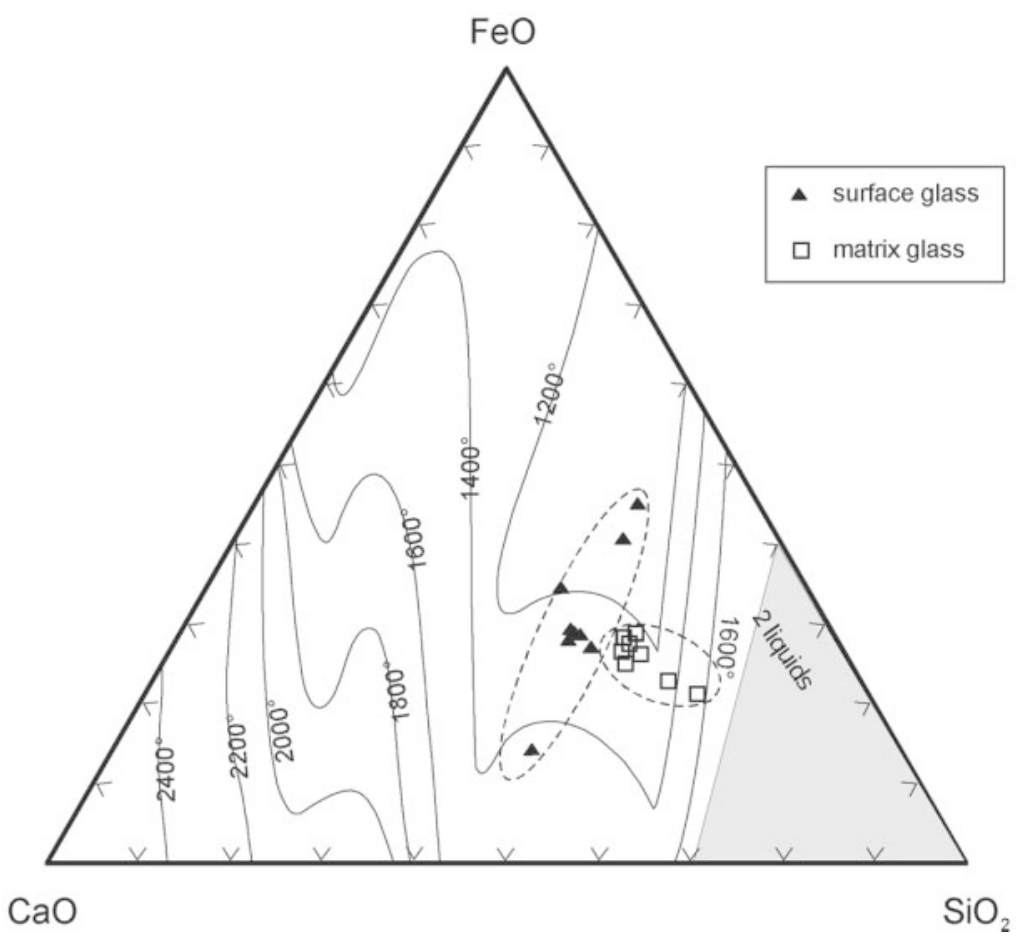

FIG. 5. Position of glass samples in the ternary system $\mathrm{FeO}-\mathrm{CaO}-\mathrm{SiO}_{2}$ showing temperature contours on the liquidus (Eusden et al. 1999) $(n=16)$.

enrichment in $\mathrm{Si}$ and $\mathrm{Al}$, with respect to the unleached glass. Comparable leaching effects were observed by comparing SEM/EDS results on fresh and weathered glass along cracks and fissures in the slag.

The development of secondary phases may be seen in banded layers up to $20 \mu \mathrm{m}$ thick, deposited upon

TABLE 5. COMPOSITION OF COMPLEX SECONDARY PRECIPITATES FROM THE "DEPOSTTION" WEATHERDMG ZONE DN THE METALLLRGICAL SLAGS OF PRIBRAM

\begin{tabular}{|c|c|c|c|c|}
\hline & layer 1 & layer 2 & layer 3 & layer 4 \\
\hline 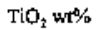 & 0.22 & 0.18 & 0.07 & 030 \\
\hline $\mathrm{SiO}_{2}$ & 1270 & 16.36 & 37.34 & 4691 \\
\hline $\mathrm{Al}_{2} \mathrm{O}_{2}$ & 3.58 & 1.46 & 4.42 & 524 \\
\hline FeO & 50.49 & 4.76 & $10-47$ & 1030 \\
\hline Mro & $46]$ & 000 & 0.17 & 0.14 \\
\hline $\mathrm{MgO}$ & 1.26 & 0.13 & 0.39 & 0.47 \\
\hline $\mathrm{CHO}$ & 8.55 & 0.28 & 042 & 0.49 \\
\hline $\mathrm{Na}_{1} \mathrm{O}$ & 0.20 & 0.14 & 0.20 & 0.77 \\
\hline $\mathrm{K}_{2} \mathrm{O}$ & 0.25 & 0,56 & 1.07 & 2.16 \\
\hline $\mathrm{PbO}$ & 0.47 & 52.65 & 17.60 & 9.98 \\
\hline $2 n 0$ & 8.62 & 0.12 & 1.51 & 0.63 \\
\hline $\mathrm{SO}_{\mathrm{k}}$ & 1.03 & 14.96 & 7.28 & 2.83 \\
\hline $\mathrm{As}_{7} \mathrm{O}_{3}$ & 0.00 & 1.15 & 2.17 & 0.11 \\
\hline totall & 91.98 & 92.72 & 83.09 & 8G.33 \\
\hline
\end{tabular}

leached (Figs. 2e, 6) or unleached glass (Fig. 7a) at the cast surface. These precipitates appear more or less crystallized and are difficult to identify owing to the submicroscopic size of individual layers. Tentative electronmicroprobe analytical data (Table 5) reveal a rather complex chemical composition, with the dominant presence of $\mathrm{Fe}, \mathrm{Si}, \mathrm{Al}, \mathrm{Ca}, \mathrm{Pb}, \mathrm{As}$ and $\mathrm{Zn}$. Some of the precipitates show a compositional resemblance to (Fe, $\mathrm{Zn}, \mathrm{Mn}$ )-oxyhydroxides (layer 1, Table 5) and $\mathrm{Pb}$ sulfate (layer 2, Table 5) containing small amount of clays or possibly amorphous silica (layer 3 and 4, Table 5). The low analytical totals may be due to hydration of the layers or to the possible presence of trivalent iron. X-ray maps of $\mathrm{Fe}, \mathrm{Zn}, \mathrm{Pb}, \mathrm{S}, \mathrm{Si}$ and $\mathrm{As}$ (Fig. 7b) performed on this weathering zone reveal the distribution of these elements within the different layers. Some of the layers are considerably enriched in As and other trace elements (Fig. 7b, layer 3, Table 5).

\section{DisCUSSION}

\section{Composition of silicates, oxides and glass}

Olivine. The general occurrence of olivine-group phases in metallurgical slag has been described by many authors (e.g., Chaudhuri \& Newesely 1993, Gasser et 

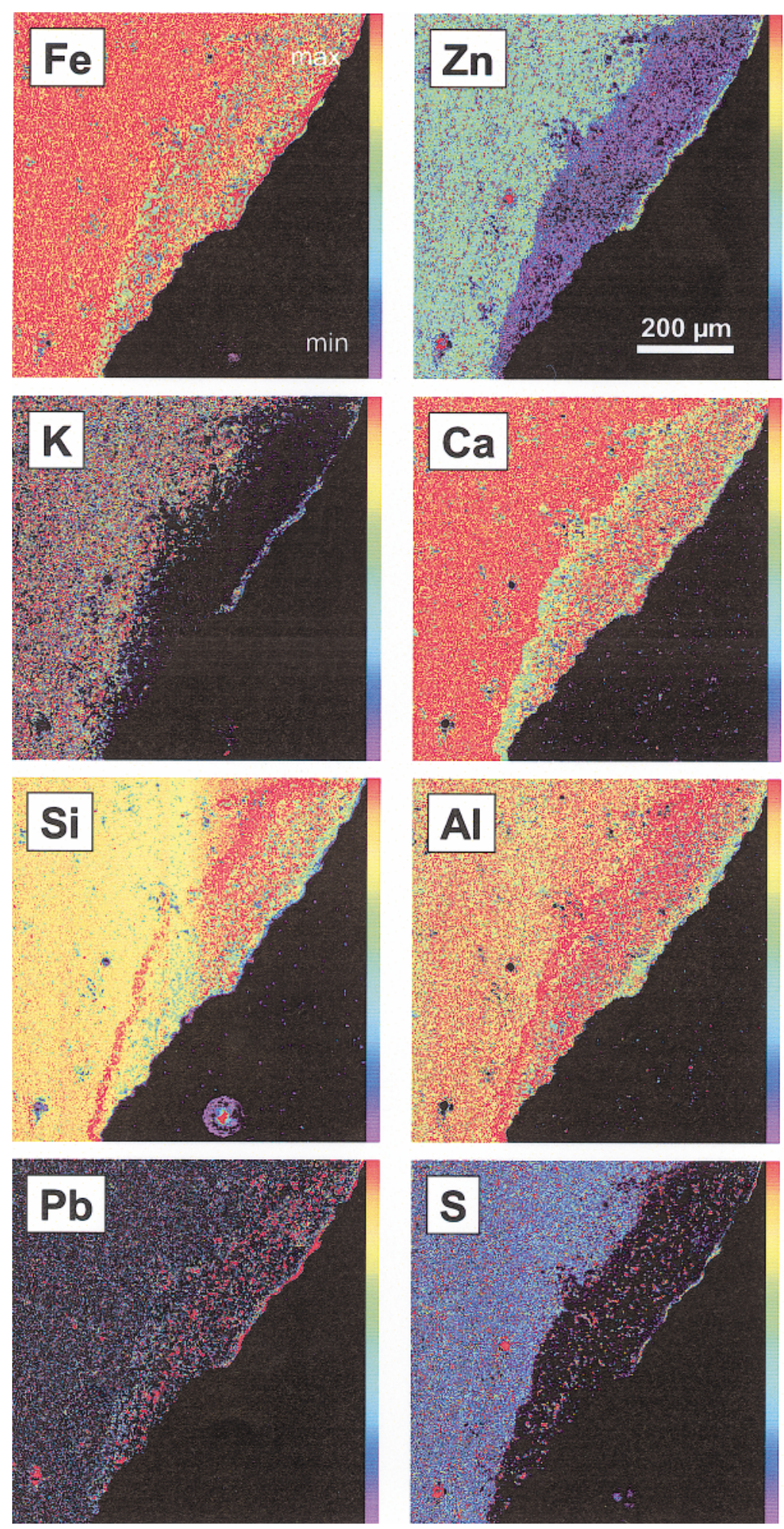
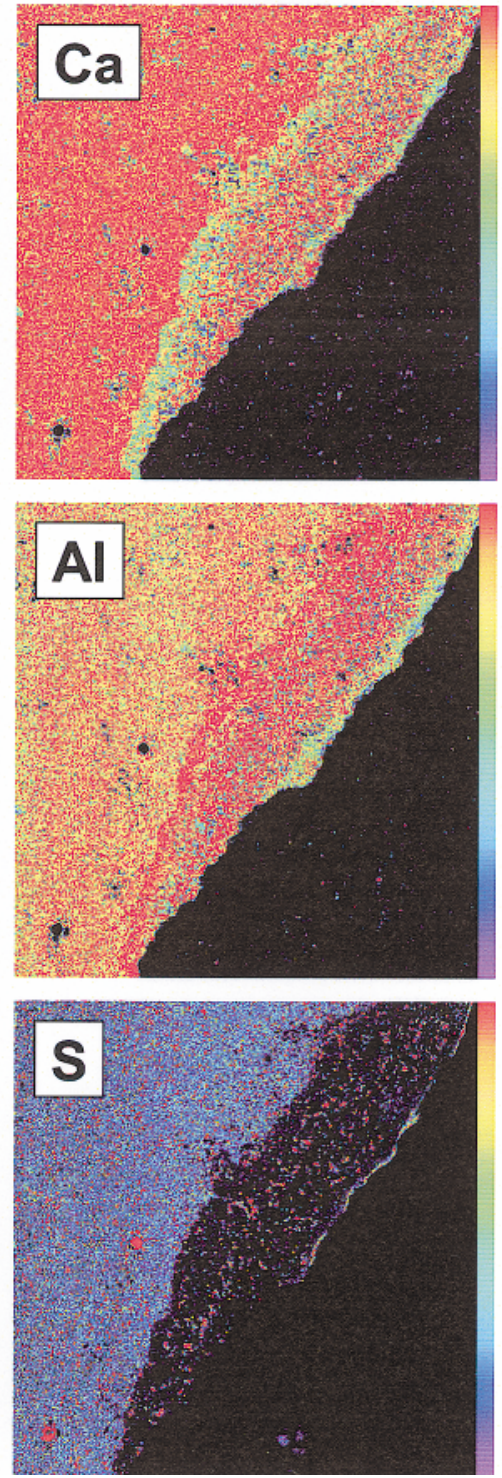

FIG. 6. X-ray maps of the "leached" weathering zone shown in Figures $2 \mathrm{e}$ and $2 \mathrm{f}$, displaying the relative distribution of Fe, $\mathrm{Zn}, \mathrm{K}, \mathrm{Ca}, \mathrm{Si}, \mathrm{Al}$, $\mathrm{Pb}$, and $\mathrm{S}$. 

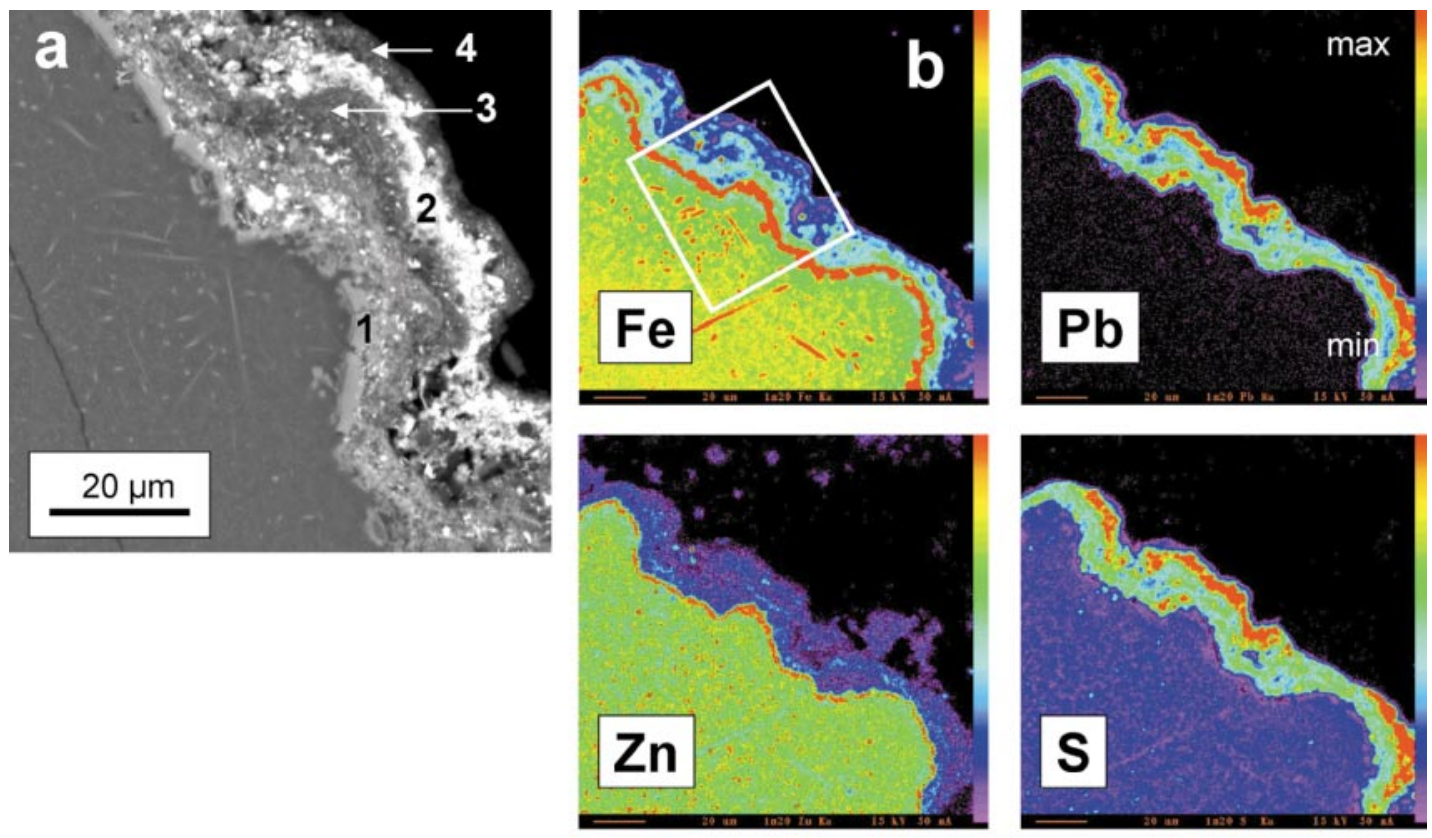

FIG. 7. Secondary phases on the slag surface. a) Back-scattered electron image of the "deposition" zone of weathering. The layers correspond to compositions in Table 5. b) X-ray maps of the zone showing the relative distribution of $\mathrm{Fe}, \mathrm{Pb}, \mathrm{Zn}, \mathrm{S}, \mathrm{Si}$, and $\mathrm{As}$.
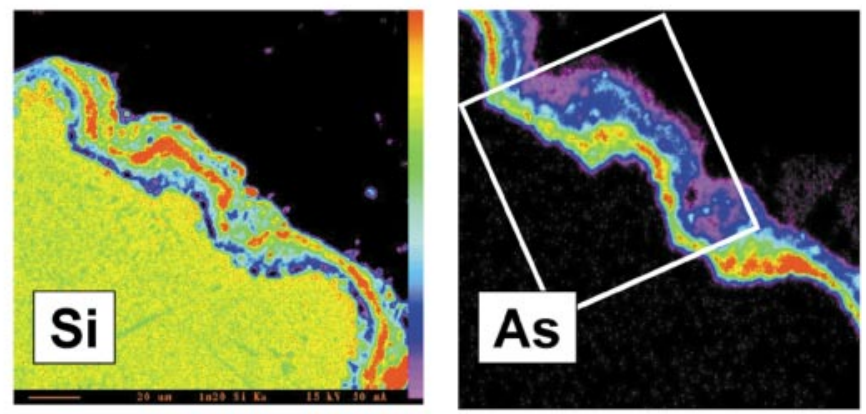

al. 1996, Kucha et al. 1996). As an early silicate (assemblages I and II), olivine contains low concentrations of Ca in the structure, as Kucha et al. (1996) also found in metallurgical slags from Belgium. Similar low-Ca olivine (3.34 wt\% $\mathrm{CaO}$ ) has also been described by Chaudhuri \& Newesely (1993) from old slag from Harz Mountain, Germany. The early crystallization of Capoor olivine, compositionally close to fayalite, can result from initially Ca-depleted slag melt, restricting any formation of typical Ca-bearing phase, such as melilite. A similar phenomenon is also typical for Ca-poor Middle Age slag (Ettler et al. 2000). In contrast, the initial melts of slag from assemblages III and IV are likely $\mathrm{Ca}$-enriched and permit the early formation of $\mathrm{Ca}$ bearing phases (melilite, clinopyroxene) and the late formation of Ca-rich olivine.

Elevated contents of $\mathrm{Mn}$ in olivine (e.g., anal. 5, Table 2) reflect reducing conditions (Folco \& Mellini 1997) and show that the majority of the divalent man- ganese is scavenged from the silicate melt by olivine; compared to other phases, olivine is the most effective concentrator of Mn. High concentrations of zinc (up to $6.28 \mathrm{wt} \% \mathrm{ZnO}$ ) are strictly related to its substitution for divalent iron in the structure (Chaudhuri \& Newesely 1993, Ericsson \& Filippidis 1986). The absence or the trace amount of efficient concentrators of $\mathrm{Zn}$ (melilite, spinel) in assemblages I and II results in the more extensive entry of $\mathrm{Zn}$ into the early olivine (Table 2). Similarly, slightly higher $\mathrm{Zn}$ contents in olivine from assemblage IV (anal. 6, Table 2), compared to olivine from assemblage III (anal. 4, 5, Table 2) are likely due to the absence of $\mathrm{Zn}$-bearing clinopyroxene in the assemblage.

Clinopyroxene. Clinopyroxene-group phases, common in slags and similar vitrified materials, are of two main types; (i) diopside and augite-aegirine series (Clozel-Leloup et al. 1999) and (ii) hedenbergite (Chaudhuri \& Newesely 1993, Wearing 1983). Their 
chemical composition in vitrified waste varies widely depending on the different technologies used in smelting and the chemical composition of the processed materials. Compared to aluminous hedenbergite from tin slag studied by Wearing (1983), the clinopyroxene at Príbram is slightly Fe-enriched (average: $23.26 \mathrm{wt} \%$ $\mathrm{FeO}$ ), slightly Al-depleted (average: $8.07 \mathrm{wt} \% \mathrm{Al}_{2} \mathrm{O}_{3}$ ), and the concentration of $\mathrm{Zn}$ is significantly higher (average: $2.26 \mathrm{wt} \% \mathrm{ZnO}$ ). In some cases, the clinopyroxene contains more than $50 \%$ of the $\mathrm{Ca}_{2} \mathrm{Si}_{2} \mathrm{O}_{6}$ component (Fig. 4; anal. 8, 9 and 11, Table 2), and the effect of the petedunnite and johannsenite components on the $\mathrm{Ca}-$ $\mathrm{Mg}-\mathrm{Fe}$ classification must be considered. According to Morimoto (1989), a bulk-composition with relatively high contents of $\mathrm{Zn}$ and $\mathrm{Mn}$ substituting for $\mathrm{Fe}^{2+}$ will displace the analytical points below the $50 \% \mathrm{Ca}_{2} \mathrm{Si}_{2} \mathrm{O}_{6}$ line in the Wo-En-Fs diagram. Morimoto (1989) does not mention any specific crystallochemical site for $\mathrm{Pb}$ in the structure of clinopyroxenes. Alternatively, $\mathrm{Pb}$-rich submicroscopic droplets trapped within the clinopyroxene could account for the values encountered.

Melilite. Melilite-group phases commonly form in slag (Kucha et al. 1996, Deer et al. 1986) and apparently nucleate during the spinel phase of crystallization. Compared to melilite from slag samples resulting from similar processing of polymetallic ore, as studied by Kucha et al. (1996), the melilite at Příbram is relatively Fe-poor ( $<9 \mathrm{wt} \% \mathrm{FeO})$ and contains slightly higher concentrations of $\mathrm{Zn}(10.5 \mathrm{wt} \% \mathrm{ZnO})$ and significantly higher amounts of $\mathrm{Ca}(37.3 \mathrm{wt} \% \mathrm{CaO})$. Melilite crystallizes only in Ca-rich melts and forms in both slowly cooled and quenched slag (assemblages III and IV, respectively). Melilite is the most important $\mathrm{Zn}$-bearing silicate. Slightly elevated contents of zinc in melilite from assemblage IV may be caused by the absence of clinopyroxene, which, as in assemblage III, can also significantly concentrate $\mathrm{Zn}$. The presence and localization of $\mathrm{Pb}(0.35 \mathrm{wt} \% \mathrm{PbO}$, i.e., 0.005 atoms per formula unit $)$ are as poorly documented as in the clinopyroxene, but it appears that $\mathrm{Pb}$ (ionic radius $1.2 \AA$ ) could replace $\mathrm{Ca}$ (ionic radius $1.0 \AA$ ) in a distorted position of the structure. Melilite is also a common phase in bottom ash from municipal solid-waste incinerators (MSWI), but such melilite is more aluminous and magnesian (Eusden $e t$ al. 1999).

Spinels. With the exception of assemblage I, the general sequence of crystallization of the silicate melt starts with the formation of a spinel-group phase, which is the dominant concentrator of $\mathrm{Zn}$ (up to $19.9 \mathrm{wt} \% \mathrm{ZnO}$ ). Similar values were noticed by Kucha et al. (1996) in $\mathrm{Pb}-\mathrm{Zn}$ metallurgical slag from Belgium (up to 18.48 wt\% $\mathrm{ZnO}$ ). Although rich in zinc, the spinel is persistent, which will severely limit the mobility of this element during the weathering process (Johnson 1994). The lack of spinel in assemblage I and the low percentage of spinel in assemblage II result in the incorporation of $\mathrm{Fe}$, which would otherwise be taken up by magnetite, into the olivine structure $(<55.57 \mathrm{wt} \% \mathrm{FeO})$.
A spinel-group phase with the composition of magnetite rather than gahnite or franklinite is observed typically in other types of vitrified waste (e.g., MSWI bottom ash) (Eusden et al. 1999, Clozel-Leloup et al. 1999).

Glass. Compared to surface glass, matrix glass is depleted in elements such as $\mathrm{Fe}, \mathrm{Mn}$ and $\mathrm{Ca}$, which enter the crystalline phases, and enriched in elements whose entry into the structures of crystallizing phases is limited. These "incompatible" elements, accumulated in the residual liquid, are typically the alkalis and $\mathrm{Pb}$. The slightly lower zinc content in matrix glass is related to a compatible behavior of zinc, which enters into the structures of previously crystallized oxides and silicates. Both surface and matrix glasses from slag, plotted in the ternary system $\mathrm{FeO}-\mathrm{CaO}-\mathrm{SiO}_{2}$ (Fig. 5), correspond to "opaque" glass from bottom ash of municipal solidwaste incinerators (MSWI), as determined by Eusden et al. (1999). Estimations of temperatures, given by the position of the quenched surface glasses in the system $\mathrm{FeO}-\mathrm{CaO}-\mathrm{SiO}_{2}$ (Fig. 5), show a mean value of $1300^{\circ} \mathrm{C}$, which is frequently cited as the temperature of fusion attained in the blast furnace (K. Vurm, pers. commun., 1999).

\section{Metal mobility}

As expected, the weathered zones show that crystalline phases of the slag are more stable than glass of similar composition. Various major and minor elements $(K$, $\mathrm{Ca}, \mathrm{Fe}, \mathrm{Zn}$ ) are released from the glass structure (Fig. 6). Leaching of $\mathrm{Ca}$ and other network-modifying cations $\left(\mathrm{Mg}, \mathrm{Mn}, \mathrm{Fe}^{2+}\right)$ is a typical phenomenon, observed also by Mahé-Le Carlier et al. (2000) in Pb-Zn slag. Such a zone of leached glass becomes enriched in Si and $\mathrm{Al}$ (Fig. 6). Similar relative enrichment in $\mathrm{Si}$ and $\mathrm{Al}$ was described in weathered archeological glass (Macquet \& Thomassin 1992) and in slag (Mahé-Le Carlier et al. 2000). Leaching due to weathering results in the mobilization of Zn, contained mainly in glass (Fig. 6), and of $\mathrm{Pb}$, present in particular in sulfide droplets (Figs. 2f, 6). However, the zinc bound in crystalline phases, such as spinel, is not significantly removed during weathering (Johnson 1994). Compared to glass, the microcrystalline skeleton of $\mathrm{Zn}$-bearing olivine resists alteration (Fig. 2f) and severely limits the mobility of zinc. Lead is mobilized from submicrometric sulfide droplets, which are extracted by glass dissolution (Fig. 2f). Local $\mathrm{Pb}$-enrichment within the "leached" zone (Fig. 6) is obviously related to the dissolution of large sulfide droplets, which become surrounded by a Pb-rich aureole. Gee et al. (1997) quoted the easy dissolution of $\mathrm{Pb}$ or $\mathrm{PbS}$ spheres trapped in historical slag from Britain and the subsequent formation of $\mathrm{Pb}$-oxide or carbonate-like secondary phases. However, the immobilization process connected with the precipitation of similar phases will be possible only at the surface of the leached zone, not inside (e.g., Figs. 2e, 7). 
The surface-deposition zone (Fig. 7) probably results from the dissolution of the nearby metallic fraction (massive matte or sulfide-metallic inclusions trapped within the glass), succeeded by precipitation of secondary phases from the metal-rich solutions. The chemical composition of these precipitates is tentatively described as a complex mixture of $\mathrm{Fe}$ oxyhydroxides and $\mathrm{Pb}$ sulfates, involving other possible phases, such as clay minerals or amorphous silica (Table 5, Fig. 7). The fracture fillings, composed of newly formed precipitates similar to Fe oxyhydroxides, were commonly encountered by Mahé-Le Carlier et al. (2000) in historical metallurgical slag. Lead sulfate also was identified by Lastra et al. (1998) as one of the principal $\mathrm{Pb}$-controlling phases during the experimental alteration of $\mathrm{Pb}-\mathrm{Zn}$ slag.

\section{Phase chemistry - assemblage relationship}

The composition of the phases bears a direct relationship with the bulk composition of the melt and with the cooling regime, which control the crystallization sequence in the slag. Two distinct group were determined in this paper. (i) Assemblages I and II are dominated by fayalite, crystallizing probably from initially Ca-depleted slag melt. The presence of clinopyroxene in phase assemblages reveals a relatively slow rate of cooling of the initial slag melt (Ettler et al. 2000). (ii) Assemblages III and IV are dominated by efficient Caconcentrators (melilite) and result from an initially $\mathrm{Ca}-$ rich melt. Owing to the presence of clinopyroxene, assemblage III forms in slowly cooled slag, contrary to assemblage IV, which appears to form as a result of quenching.

As crystallization of the silicate melt proceeds, $\mathrm{Zn}$ and $\mathrm{Pb}$ are redistributed among several crystalline phases (silicates, oxides, sulfide or metallic phases) and residual glass, and the two elements show contrasting behavior. Zinc, being nearly totally dissolved in the silicate melt, is partially incorporated into the structures of oxides (spinels), silicates (clinopyroxene, melilite, olivine), sulfides (sphalerite or wurtzite) and glass. Lead behaves as an "incompatible element" and is concentrated in residual glass and in $\mathrm{Pb}$-rich sulfide or metallic inclusions trapped in the glass. Lead is not significantly incorporated into the silicates and oxides, and the elevated $\mathrm{Pb}$ contents of some silicate phases may be due, at least in part, to trapped submicrometric $\mathrm{Pb}$-rich inclusions.

The study shows that crystalline silicates and oxides, exposed to weathering, are very stable. The only phase that appears to undergo weathering is the glass. Slag with a high glass content is, therefore, potentially environmentally more hazardous (Eusden et al. 1999) than fully crystalline slag. However, the weathered zones observed in the glass are rare, and the mass of surface glass involved is minor in comparison with the amount of dumped slag. Hence, compared to the metallic fraction (matte), silicate slag on the stockpiles of Př́bram probably does not represent an important source of pollution. The potential environmental risk related to the release of zinc and lead contained in the silicates, the oxides and the glass remains limited.

\section{ACKNOWLEDGEMENTS}

The authors thank Zdeněk Kunický, the director of Př́bram smelter (Kovohutě Př́bram a.s.) for permission to access slag samples on the dumps and for his support during the laboratory study. M. Karel Vurm is thanked for fruitful discussions on smelting technology. The study was supported by BRGM Orléans, by the Université d'Orléans, and by grants J13/98:113100005 and 208/2000/B GEO from the Charles University of Prague. The referees, J. Dykstra Eusden Jr. and J. Donald Rimstidt, are acknowledged for their helpful comments, on an earlier version of the manuscript.

\section{REFERENCES}

AtZeni, C., Massidda L. \& SAnNa, U. (1996): Use of granulated slag from lead and zinc processing in concrete technology. Cement Concrete Res. 26, 1381.

Borůvka, L., Huan-Wei, C., KozÁK, J. \& KrištoufKová, S. (1996): Heavy contamination of soil with cadmium, lead and zinc in the alluvium of the Litavka river. Plant Production (Ros. Vyroba) 42, 543-550.

Chaudhuri, J.N.B. \& Newesely, H. (1993): Mineralogical characterization of old Harz Mountain slags. Can. Metall. Quart. 32, 1-12.

Clozel-Leloup, B., Bodénan, F. \& Piantone, P. (1999): Bottom ash from municipal solid waste incinerator: mineralogy and distribution of metals. In Waste Stabilization and Environment (J. Méhu, L. Grelier-Volatier \& T. Burleigh, eds.). Société Alpine de Publication, Lyon, France (46-51).

DeER, W.A., HowIE, R.A. \& Zussman, J. (1986): Rock-Forming Minerals. 1B. Disilicates and Ring Silicates (second ed.). John Wiley \& Sons, New York, N.Y.

ERICSSON, T. \& FilipPIDIS, A. (1986): Cation ordering in the limited solid solution $\mathrm{Fe}_{2} \mathrm{SiO}_{4}-\mathrm{Zn}_{2} \mathrm{SiO}_{4}$. Am. Mineral. 71, 1502-1509.

Essene, E.J. \& PeAcoR, D.R. (1987): Petedunnite (CaZnSi $\left.{ }_{2} \mathrm{O}_{6}\right)$, a new zinc clinopyroxene from Franklin, New Jersey, and phase equilibria for zincian pyroxenes. Am. Mineral. 72, 157-166.

EtTler, V., BAILlif, P. \& Touray, J.-C. (1999): Natural weathering of glass from $\mathrm{Pb}$-metallurgical slag: a comparison with laboratory leaching test using XPS. Bull. Liaison Soc. fr. Minéral. Cristallogr. 11, 146-147.

Johan, Z., Touray, J.-C. \& JelíneK, E. (2000): Zinc partitioning between glass and silicate phases in historical and modern lead-zinc metallurgical slag from the Př́bram district, Czech Republic. C. R. Acad. Sci. Paris 331, 245-250. 
Eusden, D.J., Eighmy, T.T., Hockert, K., Holland, E. \& Marsella, K. (1999): Petrogenesis of municipal solid waste combustion bottom ash. Appl. Geochem. 14, 10731091 .

Folco, L. \& Mellini, M. (1997): Crystal chemistry of meteoritic kirschteinite. Eur. J. Mineral. 9, 969-973.

Gasser, U.G., Walker, W.J., DAhlgren, R.A., Borch, R.S. \& BURAU, R.G. (1996): Lead release from smelter and mine waste impacted materials under simulated gastric conditions and relation to speciation. Environ. Sci. Technol. 30 , 761-769.

Gee, C., Ramsey, M.H., Maskall, J. \& Thornton, I. (1997): Mineralogy and weathering processes in historical smelting slag and their effect on the mobilisation of lead. $J$. Geochem. Explor. 58, 249-257.

Gervais, C., Barna R., Moszkowicz, P. \& Méhu, J. (1999): Leaching behaviour of construction materials containing waste in specified conditions: case of primary lead and zinc slag. In Waste Stabilization and Environment (J. Méhu, L. Grelier-Volatier and T. Burleigh, eds.). Société Alpine de Publication, Lyon, France (329-348).

GiLchrist, J.D. (1989): Extraction Metallurgy (third ed.). Pergamon Press, Oxford, U.K.

GILL, C.B. (1980): Nonferrous Extractive Metallurgy. John Wiley \& Sons, New York, N.Y.

Hampejs, V. (1971): Anniversary of the Příbram smelter. Oblastní muzeum Podbrdska v Příbrami (Regional museum of Podbrdsko in Př́bram), Spec. Publ. (in Czech).

Johnson, C.A. (1994): Partitioning of zinc among common ferromagnesian minerals and implications for hydrothermal mobilization. Can. Mineral. 32, 121-132.

Kucha, H., Martens, A., Ottenburgs, R., De Vos, W. \& ViAENE, W. (1996): Primary minerals of $\mathrm{Zn}-\mathrm{Pb}$ mining and metallurgical dumps and their environmental behaviour at Plombières, Belgium. Environ. Geol. 27, 1-15.
KUDRNÁČ, J. (1987): Archaeological research of old mine vestiges in the Litavka valley and the Middle Ages Au-mines near Čelina. Vlastivědný sborník Podbrdska (Volume of historical studies of Podbrdsko) 38-39, 221-245 (in Czech).

Lastra, R., Carson, D. \& Koren, D. (1998): Mineralogical characterization of leachable elements in ten slags from Canadian non-ferrous sulfide smelters. In Waste Characterization and Treatment Symposium (W. Petruk, ed.). SME, Littleton, Colorado (79-90).

Legendre, O., BodÉnAn, F. \& EtTler, V. (1998): Mineralogy and weathering of $\mathrm{Pb}-\mathrm{Zn}$ slag from Příbram, Czech Republic. Int. Mineral. Assoc., $17^{\text {th }}$ Gen. Meeting (Toronto), Programme Abstr., 50.

Macquet, C. \& Thomassin, J.H. (1992): Archaeological glasses as modeling of the behavior of buried nuclear waste glass. Appl. Clay Sci. 7, 17-31.

Mahé-Le Carlier, C., Le Carlier de Veslud, C., Ploquin, A. \& ROYER, J.J. (2000): L'altération naturelle des scories de la métallurgie ancienne: un analogue de déchets vitrifiés. C.R. Acad. Sci. Paris 330, 179-184.

Mandin, D. (1999): Which application for lead and zinc primary smelter slag? In Waste Stabilization and Environment (J. Méhu, L. Grelier-Volatier and T. Burleigh, eds.). Société Alpine de Publication, Lyon, France (305-310).

Morimoto, N. (1989): Nomenclature of pyroxenes. Can. Mineral. 27, 143-156.

RIEUWERTS, J. \& FARAGO, M. (1996): Heavy metal pollution in the vicinity of a secondary lead smelter in the Czech Republic. Appl. Geochem. 11, 17-23.

WEARING, E. (1983): Crystal-liquid partition coefficients for pyroxene, spinels, and melilite, in slag. Mineral. Mag. 47, 335-345.

Received June 20, 2000, revised manuscript accepted March 7, 2001. 